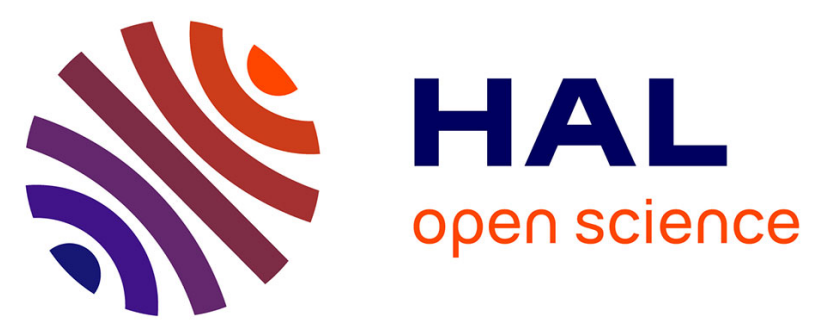

\title{
Environmental control on a land-sea transitional setting: integrated sedimentological, geochemical and faunal approaches
}

Eric Armynot Du Chatelet, Viviane Bout-Roumazeilles, Rodolfo Coccioni, Fabrizio Frontalini, Fabio Francescangeli, Giulia Margaritelli, Roberto Rettori, Federico Spagnoli, Federica Semprucci, Alain Trentesaux, et al.

\section{To cite this version:}

Eric Armynot Du Chatelet, Viviane Bout-Roumazeilles, Rodolfo Coccioni, Fabrizio Frontalini, Fabio Francescangeli, et al.. Environmental control on a land-sea transitional setting: integrated sedimentological, geochemical and faunal approaches. Environmental Earth Sciences, 2016, 75 (2), pp.123. 10.1007/s12665-015-4957-7 . hal-01271095

\section{HAL Id: hal-01271095 \\ https://hal.science/hal-01271095}

Submitted on 29 Jul 2021

HAL is a multi-disciplinary open access archive for the deposit and dissemination of scientific research documents, whether they are published or not. The documents may come from teaching and research institutions in France or abroad, or from public or private research centers.
L'archive ouverte pluridisciplinaire HAL, est destinée au dépôt et à la diffusion de documents scientifiques de niveau recherche, publiés ou non, émanant des établissements d'enseignement et de recherche français ou étrangers, des laboratoires publics ou privés. 


\title{
Environmental control on a land-sea transitional setting: integrated sedimentological, geochemical and faunal approaches
}

Eric Armynot du Châtelet ${ }^{1}$, Viviane Bout-Roumazeilles ${ }^{1}$, Rodolfo Coccioni ${ }^{2}$, Fabrizio Frontalini $^{2}$, Fabio Francescangeli ${ }^{1,2,3}$, Giulia Margaritelli ${ }^{3}$, Roberto Rettori ${ }^{3}$, Federico Spagnoli $^{4}$, Federica Semprucci ${ }^{2}$, Alain Trentesaux $^{1}$, Nicolas Tribovillard $^{1}$

${ }^{1}$ UMR 8187, LOG, Laboratoire d'Océanologie et de Géosciences, Univ. Lille, CNRS, Univ. Littoral Cote d'Opale, 59000 Lille, France

${ }^{2}$ Universitá degli Studi di Urbino "Carlo Bo", DiSTeVA, Campus Scientifico Enrico Mattei, Localitá' Crocicchia, 61029 Urbino, Italy

${ }^{3}$ Universita Degli Studi Di Perugia, Dipartimento di Scienzedella Terra, Piazza Universitá, 06123 Perugia, Italy

${ }^{4}$ Consiglio Nazionale delle Ricerche, Istituto di Scienze Marine (ISMAR), Largo Fiera dellaPesca, 60125 Ancona, Italy

* corresponding author : Eric Armynot du Châtelet, eric.armynot@univ-lille1.fr

\begin{abstract}
Because of their location at the interface between sea and emerged lands, so-called transitional environments are characterized by strong spatial and temporal variability in terms of sedimentological, physicochemical, and geochemical parameters. An increasing number of studies put forward the use of bioindicators as a tool for environmental monitoring. However, the sensitivity to these environmental parameters is commonly tested separately, even though it is known that interactions are numerous within this complex ecosystem. An integrated methodological study was conducted in Lake Varano (Italy). On the basis of 45 spatially distributed samples throughout the area and selected environmental parameters (trace elements, organic matter, clay mineral assemblages, grain size of sediment, and water characteristics), four factors are identified. The Lake Varano ecosystem is predominantly influenced by terrigenous inputs (first-order factor). The clastic fractions of the sediments supply a large range of trace elements, occasionally in relatively high concentrations. Under such circumstances, despite occasionally exceeding of threshold limits, the trace element pollution can generally be ruled out. The organic content combined with depth is the second key factor. In Lake Varano, the organic content is high and may lead to seasonal
\end{abstract}


eutrophication. As a third-order factor, although only analyzed once, oxygen, ORP, salinity, and $\mathrm{pH}$ gradients show that foraminiferal diversity is positively influenced by more saline conditions. The fourth-order factor is the sediment size. To conclude, this paper illustrates the interest in and need to conduct a detailed, integrated, sedimentological study of a site prior to any examination of its ecological status (possible occurrences of sources of pollution).

\section{Keyword}

Environmental monitoring - Trace elements - Organic matter - Foraminifera - Meiobenthos Pollution

\section{Introduction}

Transitional environments (TEs), namely estuaries, coastal lakes, and lagoons, are dynamic and complex ecosystems. Because of their location between sea and land, they are influenced by strong spatial and temporal variability of sedimentological, physicochemical and geochemical parameters (Dauvin and Ruellet 2009; Frontalini et al. 2011a, 2011b). TEs play an important economic role and are among the most productive aquatic systems (Nixon 1988). These environments make up almost $13 \%$ of the world's coastlines and around half of the Mediterranean coastline. Italian TEs are exploited for extensive or semi intensive aquaculture or as nursery areas (Barnes 1991). The great variability in their chemical, physical, and hydrological parameters makes TEs typically unstable environments (Millet and Guelorget 1994). As a consequence, the concept of short- or long-term variations is relative for these ecosystems when compared to marine environments (Marzano et al. 2003). TEs are normally influenced by numerous environmental factors that commonly complicate understanding of them. Factors are classified as natural (e.g., sediment grain size, organic matter abundance, salinity) and anthropogenic (pollution from industrial, domestic, and agricultural sources). The multiple sources and variability of these factors/inputs within the environment imply that the equilibrium with fauna is delicate. Foraminifera and meiobenthos living in these environments are known to be particularly suitable for environmental biomonitoring purposes (Frontalini and Coccioni 2011; Semprucci et al. 2013, 2015). However, most studies use parameters that were separately considered and conduct no true spatial analysis of the data that takes into account the positioning of the characteristics (distance) between the points.

The particularly innovative objective of the study is to shed light on an alternative way by which to evaluate the TE of Varano, and here we propose a methodological attempt based 
on advanced statistical and geostatistical interpretations. By using these tools, the final aim of that paper is to recognize groups of environmental parameters (trace elements, organic matter, clay mineral assemblages, sediment grain size, and water characteristics) and to possibly define their influence on biota in the coastal Lake of Varano in Italy. The study is intended for the calibration of these parameters in the natural environment, with a particular emphasis on the spatial constraints of the analyzed variables (in situ sediment, texture, organic matter and trace element content, clay mineral assemblages, and water masses). Accordingly, this study is grounded in both a classical and a spatial approach; the combination of these parameters allows us to characterize the faunal habitats on a multiple spatial scale: from a local influence to the influence of an entire area and geological setting.

\section{Study area}

Lake Varano is a coastal lake located on the north side of the Gargano National Park (southeast Italy) and covers an area of $\sim 65 \mathrm{~km} 2$. The average water depth is $\sim 4 \mathrm{~m}$, with a maximum of $\sim 6 \mathrm{~m}$ in the center (Spagnoli et al. 2002; Molinaroli et al. 2014). The lake is separated from the Adriatic Sea by an $11 \mathrm{~km}$-long and $1 \mathrm{~km}$ wide coastal barrier covered by dunes. Two free connections with the open sea and hence marine water are artificially maintained through the Capoiale and Varano channels (Fig. 1). Freshwater enters the system in three ways: (1) via tributaries principally located in the southeastern part of the lake (i.e.,. the Antonino, Correntino and San Francesco rivers); (2) via drainage (agricultural and small city) watercourses from the east of the lake (Spagnoli et al. 2002; Specchiulli et al. 2008); and (3) via surface and underwater karst springs located all around the border of the lake (Polemio et al. 2000). The lake is, thus, a brackish water system. The water-mass residence time (ca. 1.5 year) is rather long as a result of a reduced exchange with the adjacent coastal marine area (Specchiulli et al. 2008). The lake is intensively used for farming mussels (Mytilus galloprovincialis) and other aquacultural products. The sediment is consequently rich in bioclasts. It has been reported that mussels face significant difficulties during the summer months because of dissolved oxygen deficiency (Breber and Scirocco 1998; Specchiulli et al. 2008). The presence of a few villages and extensive agriculture (to the east of the lake), with no significant industrial activity, characterizes the area around the lake. The Gargano geological background is composed of Jurassic and Cretaceous limestones, more marly to the east. Some Miocene sandstones are occasionally observed (Polemio et al. 2000). From a biotic point of view, the lake was characterized for microbial, zooplankton, meio- and macrobenthos contents (Specchiulli et al. 2010; Belmonte et al. 2011; Frontalini et al. 2013, 
2014; Semprucci et al. 2014; Manzari et al. 2015). In particular, Belmonte et al. (2011) recognized 55 zooplankton categories and documented their maximum and minimum abundance in the eastern and central part of the lake, respectively. The lowest abundances and diversities of the macrobenthic community were found in the central part of the lake (Specchiulli et al. 2010). On the basis of the total (living and dead) benthic foraminiferal assemblages $(>125 \mu \mathrm{m})$ analyzed in 45 sediment samples, Frontalini et al. (2013) identified two main biotopes and five sub-biotopes that reflect different ecological and environmental conditions (salinity, grain size, and organic matter). Later on, biodiversity trends of the living meiofauna and benthic foraminifera were studied at 21 stations by Frontalini et al. (2014) who revealed higher diversity values in front of the Capoiale channel and in the inner part of the lake, whereas lower values were generally found in the central and outer parts. Nematodes, copepods, and turbellarians are the major components of the meiofaunal assemblages, whereas Ammonia along with Haynesina germanica characterized the benthic foraminiferal assemblages $(>63 \mu \mathrm{m})$. The general composition and level of taxonomic diversity of the nematode assemblages are comparable with those reported for TEs worldwide (Semprucci et al. 2014). The same authors documented that the composition and biological traits of nematode assemblages are mainly affected by grain size, organic matter, pollution load index and, only secondarily, by salinity. Although the present study is based on the same stations, it includes the most up-to-date dataset of abiotic parameters including unpublished data (selected trace elements for all stations, clay mineralogy, and additional benthic foraminiferal data).

\section{Materials and methods}

\section{Sample collection and bottom water characteristics}

This study is based on 45 bottom (ca. $2 \mathrm{~cm}$ ) sediment samples collected from Lake Varano in late March 2012 (Fig. 1). The samples were taken using a Van Veen grab sampler device that collects sediment over a surface area of about $400 \mathrm{~cm}^{2}$. The entire surface is collected and mixed to avoid potential bias induced by microvariability in the distribution of the fauna. At each station and at the water/ sediment interface, the temperature, $\mathrm{pH}$, salinity, oxygen reduction potential (ORP), and dissolved oxygen (DO) content of the seawater were measured. The positions of the sampling stations were determined using a GPS device (Appendix 1 in ESM). Three aliquots from each sample were taken at each station and stored 
in polyethylene jars. The first aliquot (for all of the 45 samples) was used for grain size, mineralogical, and organic and inorganic geochemical analyses, the second (25 of the 45 samples) for a study of the foraminiferal assemblages, and the third for the meiobenthic analysis (21 of the 45 samples) (Fig. 1).

Sediment characteristics

Grain size, organic matter, and calcium carbonate analyses

Grain size and organic matter $(\mathrm{OM})$ methodologies have been reported (Frontalini et al. 2013, 2014; Semprucci et al. 2014). Organic matter composition and abundance were characterized in terms of total organic carbon (TOC) content and $\mathrm{C} / \mathrm{N}$ ratio to determine whether the dominant organic carbon was marine or continental in origin (Armynot du Châtelet et al. 2009a, 2013). The calcium carbonate content was determined to assess the quantity of the shell debris of the benthic fauna. It was determined using a Bernard calcimeter (acid-digestion and $\mathrm{CO}_{2}$ volume measurement) and expressed as a dry sediment weight percentage. Measurements were carried out in triplicate for each station using $0.4 \mathrm{~g}$ of finely crushed dry sediment each time.

\section{Trace elements}

The trace element concentrations were primarily determined to characterize the geochemical background of the lake and thereafter evaluate the degree of anthropogenic contamination. Activation Laboratories Ltd. (Ontario, Canada) determined the concentrations of 23 major trace elements (Al, Fe, Ca, K, Mg, Mn, Na, P, Ti, As, Cd, Co, Cr, Cu, La, Ni, Pb, $\mathrm{Sc}, \mathrm{Sr}, \mathrm{V}, \mathrm{Y}, \mathrm{Zn}$, and $\mathrm{Zr}$ ) using inductively coupled plasma optical emission spectrometry (ICP-OES). The finely crushed sediment $(\sim 0.5 \mathrm{~g})$ was digested with aqua regia (a combination of concentrated hydrochloric and nitric acids to leach sulfides, some oxides and some silicates - $0.5 \mathrm{ml} \mathrm{H} 2 \mathrm{O}, 0.6 \mathrm{ml}$ concentrated $\mathrm{HNO}_{3}$ and $1.8 \mathrm{ml}$ concentrated $\mathrm{HCl}$ - for $2 \mathrm{~h}$ at $95^{\circ} \mathrm{C}$ ). The sample was then cooled and diluted to $10 \mathrm{ml}$ with de-ionized water and homogenized. The samples were analyzed using a Perkin Elmer OPTIMA 3000 Radial ICP for the element suite. A standard matrix and a blank were run every 13 samples. A series of USGS-geochemical standards were used as controls (Appendix 2 in ESM). Al-normalization is used to minimize the effects of element dilution by carbonate or biogenic silica, although certain caveats may apply to this approach (Tribovillard et al. 2006). The linear relationship between $\mathrm{Al}$ and a given element means that this element has a probable terrigenous origin. 


\section{Clay mineralogy}

Clay minerals are primarily derived from the weathering of the rocks of the surroundings, being brought to lakes by winds/rivers, or coming from more distant sources through marine currents. They may also originate from the in situ alteration of some minerals. The observation of the composition of clay mineral assemblages was therefore used to evaluate the major sources of the sediment deposited within Lake Varano. In order to determine the clay mineral assemblage, all the samples were first decalcified with $0.2 \mathrm{~N}$ of hydrochloric acid. The excess acid was removed by $\mathrm{H}_{2} \mathrm{O}$ washing and repeated centrifugations. The clay sized fraction $(<2 \mu \mathrm{m})$ was isolated by settling, and oriented on glass slides (oriented mounts). Three X-ray diffraction (XRD) determinations were performed on: (a) untreated samples; (b) glycolated samples (after saturation for $12 \mathrm{~h}$ in ethylene glycol); and (c) samples heated at $490^{\circ} \mathrm{C}$ for $2 \mathrm{~h}$ (Bout-Roumazeilles et al. 1999). The analyses were run on a Brucker Endeavor D4 diffractometer coupled with a LynkEye detector between $2.49^{\circ}$ and $32.5^{\circ} 2 \theta$. Each clay mineral was then characterized by its layer plus interlayer interval, as revealed by an XRD analysis (Brindley and Brown 1980). Smectite was characterized by a peak of $14 \AA$ on the untreated sample test, which expanded to $17 \AA$ after saturation in ethylene glycol, before retracting to $10 \AA$ after heating. Illite presented with a basal peak of $10 \AA$ in the three tests (natural, glycolated, and heated). Chlorite was characterized by peaks at $14,7,4.72$, and $3.53 \AA$ on the three tests. Kaolinite was characterized by peaks of 7 and $3.57 \AA$ on the untreated sample and after saturation in ethylene glycol, respectively. Both peaks disappear or are strongly reduced after heating. The semiquantitative estimation of the clay mineral abundances (based on the pseudo-Voigt deconvolution for the doublets kaolinite-chlorite-3.57-3.53 ) was performed using the MacDiff software developed by Petschick (1997). The error in the reproducibility of the measurements was estimated to be $<5 \%$ for each clay mineral, as confirmed by the analysis of the replicate samples. Illite crystallinity (IK) and the Esquevin Index were measured on Xray diffraction diagrams. The illite crystallinity $\left({ }^{\circ} 2 \theta\right)$ corresponds to the width at halfmaximum height measured on the (001) peak (10 $\AA$ ). Low IK values indicate well crystallized illite that has been submitted to moderate-high metamorphism. The Esquevin Index (EI = illite intensity at $5 \AA$ /illite intensity at $10 \AA$ ) (Esquevin 1969) was used to evaluate the chemical composition of the illite (Al-rich vs. Fe/Mg-rich). All of the samples characterized by their clay mineral assemblages were subdivided using a cluster analysis (CA). Euclidean 
distance correlation coefficients were used to measure similarities and the Ward's linkage method was utilized to arrange pairs and groups into hierarchic dendrograms.

\section{Benthic faunal analyses}

The second and third set of samples was used for benthic foraminiferal and meiobenthic analyses following the methodological approach described in Frontalini et al. (2014). The dataset has already been published in Frontalini et al. (2014), but seven additional stations are considered for benthic foraminiferal analysis.

\section{Descriptive analysis}

The summary statistics were determined for all the sediment and water parameters. For the subsequent analyses, the salinity, $\mathrm{pH}$, clay fraction, and arsenic (As) contents were transformed into their common logarithms because of the strong skewness. A Pearson correlation analysis was performed with their associated $\mathrm{p}$ values. For the principal component analysis (PCA), all the abiotic data were centered to a zero mean and scaled to the unit variance. An initial PCA was carried out on the correlation matrix. The first four components were retained and rotated using Varimax rotation; the latter redistributes the variance in each variable so that each contributes strongly to one of the components and very little to the others. A second PCA was carried out on the initial transformed database in order to extract the principal component for the geostatistical analysis. The statistical analyses were carried out using the ade4, corrgram, Hmisc, plotrix and psych packages for the R software.

\section{Spatial analysis}

\section{Variogram analysis}

Variograms were used for two purposes: (1) geostatistical interpolation (an example is given in Bertazzon et al. 2006) for estimating the undetermined proportion of the unanalyzed location for foraminifera and meiobenthos (25 samples for foraminifera and 21 for meiobenthos vs. 45 for the environmental parameters); and (2) estimating the spatial distribution of the scores of each principal component extracted from the second PCA. These scores were then considered as a combination of parameters, the variations of which are concomitant. The information obtained from neighboring locations was used when estimating an unanalyzed location. We determined that the sampling scheme in Lake Varano was a truly random field and then that neighbors are equally helpful. A variogram was used to establish 
where a given case lays between these two extremes and then to suggest models for the weight function. The semivariance of one of the selected variables (foraminiferal and meiobenthic diversity and density, principal component scores) was defined as half the expected squared difference between values at places $\mathrm{x}$ and $\mathrm{x}+\mathrm{h}$. Accordingly, the variograms were calculated with Eq. 1

$\gamma(h)=\frac{1}{2 n_{h}} \sum_{i=1}^{n_{h}}\left[Z\left(x_{i}+h\right)-Z\left(x_{i}\right)\right]^{2}$

where $\gamma(h)$ is the semivariance at lag distance $h ; n(h)$ is the number of observation pairs separated by $h$; and $Z\left(x_{i}\right)$ and $Z\left(x_{i}+h\right)$ represent the paired values of the variable $Z$ at two locations separated by $h$. A semivariogram can be fitted by numerous models. The present study used exponential, spherical, and Gaussian models (respectively Eqs. 2-4), which were mixed with a nugget model most of the time (Eq. 5). The nugget represents the variability at distances smaller than the fixed sample spacing, including measurement errors.

Exponential model:

$\gamma(h)=C\left(1-\exp ^{\frac{-|h|}{a}}\right)$

Spherical model:

$\gamma(h)=\left\{\begin{array}{l}C\left(1.5\left(\frac{h}{a}\right)-0.5\left(\frac{h}{a}\right)\right)^{3} \text { if } h \leq a \\ \text { C otherwise }\end{array}\right.$

Gaussian model:

$\gamma(h)=C\left(1-\exp ^{-\left(\frac{h}{a}\right)^{2}}\right)$

Nugget:

$\gamma(h)=\left\{\begin{array}{l}0 \text { if } h=a \\ \text { C otherwise }\end{array}\right.$

These equations use $h, a$ and $C$ to represent the lag distance, the practical range and the sill, respectively. In the analysis, the sill value is the upper limit of the fitted semi-variogram model. As a consequence, the ratio of nugget to sill indicates the spatial dependency of a 
given variable (Webster and Oliver 1990, 2001). The ratios were categorized as low $(<25 \%)$, moderate $(25-75 \%)$ or strong $(>75 \%)$. A low ratio means that a large part of the variance is introduced spatially, implying the strong spatial dependency of the analyzed parameters. A high ratio commonly indicates a weak spatial dependency. The range of the semivariogram represents the average distance through which the variable semivariance reaches its peak value (Weindorf and Zhu 2010). A small effective range implies a distribution pattern composed of small patches. The theoretical model characteristics were used for kriging the data and building maps.

\section{Cross-variogram analysis}

Cross-variograms were also calculated to depict the spatial variability of the combined variables (i.e., to test the influence of the environmental parameters on the spatial distribution of the meiobenthos and foraminifera throughout the lake). The cross-variogram was calculated as follows (Eq. 6):

$\widehat{\gamma_{l \jmath}}=\frac{1}{2 m(h)} \sum_{i=1}^{m(h)}\left[\left\{Z_{u}\left(x_{i}\right)-Z_{u}\left(x_{i}+h\right)\right\} \times\left\{Z_{v}\left(x_{i}\right)-Z_{v}\left(x_{i}+h\right)\right\}\right]$

where $m(h)$ is the number of pairs of comparisons at lag $h, Z_{u}(x i)$ and $Z_{u}(x i+h)$ are the measured values of the variable $Z_{u}$, and $Z_{v}\left(x_{i}\right)$ and $z_{v}\left(x_{i}+h\right)$ are the measured values of the variable $Z_{v}$ at $x_{i}$ and $x_{i}+h$, respectively (see Baxter and Oliver (2005) and Carroll and Oliver (2005) for more explanation on the method).

The cross-variogram was modeled as follows (Eq. 7):

$\gamma_{u v}(h)=\sum_{k=1}^{K} b_{u u}^{k} g_{k}(h)$

where the $b_{u v}^{k}$ are the variances and $g_{k}(h)$ is the spatial autocorrelation.

In order to assess the degree of the so-called coregionalization, the 'hull of perfect correlation' is determined (Wackernagel 1989). The model fitted to the experimental crossvariogram must lie within this hull, formed from the line of perfect positive and negative correlation. The closer the cross-variogram to one of the lines, the stronger the coregionalization. The hull is calculated as follows (Eq. 8):

$\operatorname{Hull}\left(\gamma_{u v} \mid(h)\right)= \pm \sum_{k=1}^{K} b_{u u}^{k} b_{v v}^{k} g_{k}(h)$ 
See Wackernagel $(2003,1989)$ for more explanation.

All the geostatistical analysis was carried out using the geoR and gstat packages for the R software.

\section{Results}

\section{Bottom water characteristics}

The $\mathrm{pH}$ was alkaline, ranging from 7.4 (V8) to 8.0 (V34) (Table 1 and Appendix 1 in ESM). The salinity varied from 23.3 (V50) to 31.9 (V13) and exhibited a clear distributional pattern, with the lowest values in the outer part of the lake connected to the springs and the channel outlets. The highest salinity values were in the central and northern parts of the lake, close to the channels connected to the Adriatic Sea (Fig. 2). The ORP values ranged from $164.0 \mathrm{mV}$ (V39, V40, V41, V44, V45) to $286.0 \mathrm{mV}(\mathrm{V} 1, \mathrm{~V} 5, \mathrm{~V} 6)$, with the northern outer part of the lake exhibiting the highest ones. The DO varied between $2.7 \mathrm{mg} / \mathrm{l}$ (V8) and 15.2 $\mathrm{mg} / \mathrm{l}$ (V34) (Table 1). The highest concentrations of DO were found in the central part of the lake, whereas lower concentrations were found in connection with the two channels (Appendix 1 in ESM).

\section{Characteristics and origin of the sediments}

Sediment grain size

The bottom sediments are primarily composed of silt and sand, with the average percentages being $50 \%$ sand, $49 \%$ silt and $1 \%$ clay (Fig. 3, Appendix 1 in ESM). The highest proportion of sand is found along the sand bar on the northern part of the lake $(90 \%$ in V4) as well as in the central part. The highest proportion of silt is found in the southeastern part of the lake (sample V31: $79 \%$ ) (Fig. 3). Meanwhile, the clay fraction is never high, ranging from 0 (V1) to $5 \%$ (V31) and is only found in the eastern part of the lake (Fig. 3).

\section{Inorganic geochemistry}

The geochemistry of the sediment is strongly influenced by terrigenous inputs (Appendix 1 in ESM). No significant redox influence on the composition of the sediment was detected. Many sulfide-forming and/or redox-sensitive elements such as $\mathrm{Ni}, \mathrm{Pb}, \mathrm{Zn}, \mathrm{Co}, \mathrm{Cr}$, $\mathrm{Fe}$, and $\mathrm{V}$ are well correlated with $\mathrm{Al}$ (Pearson product-moment correlation coefficient $\mathrm{r}>0.97$, Table 2). This was also the case with $\mathrm{Ti}$ and $\mathrm{La}(\mathrm{r}>0.91)$. With respect to $\mathrm{Cu}$ (Table 2), when removing the $\mathrm{V} 38$ value (southwestern zone of the lake), the linear relationship is 
also good $(\mathrm{r}=0.95)$ as it is an outlier (the V38 sediment has $51 \mathrm{ppm}$ of $\mathrm{Cu}$, whereas the second richest sample has $33 \mathrm{ppm})$. Calcium significantly correlates with $\mathrm{Sr}(\mathrm{r}=0.96)$ and both $\mathrm{Ca}$ and $\mathrm{Sr}$ are negatively correlated with $\mathrm{Al}$ (respectively, $\mathrm{r}=-0.69$ and $\mathrm{r}=-0.62$ ). The highest $\mathrm{Ca}$ and $\mathrm{Sr}$ concentrations (respectively, up to $26.2 \%$ and $2180 \mathrm{ppm}$ ) are observed close to the southwestern border (Fig. 2). No good linear model could be calculated for the $\mathrm{Mg}-\mathrm{Al}$ pair. Cadmium and As are correlated with $\mathrm{Al}$, but the linear model is not good. The maps of the ratios $\mathrm{Cd} / \mathrm{Al}$ and $\mathrm{As} / \mathrm{Al}$ show six samples with distinctly high values (Fig. 2). All of these samples were collected along the border of the lake.

\section{Organic geochemistry}

TOC ranges from $0.16 \%$ (V4) to $5.35 \%$ (V14) (Fig. 2, Appendix 1 in ESM), while the $\mathrm{C} / \mathrm{N}$ ratio varies between $1.55(\mathrm{~V} 4)$ and 19.42 (V11). Higher values $(\mathrm{C} / \mathrm{N}>16$ and $\mathrm{TOC}>3)$ are located either in the western margins or in central zone of the lake (Fig. 2).

\section{Clay mineralogy}

Four clay minerals are observed: chlorite, illite, smectite, and kaolinite (Fig. 4a). The hierarchical analysis is based on these mineral proportion group samples in three clusters and subclusters (Fig. 4c). These clusters are clearly distributed within the lake (Fig. 4a) with a north-south distribution and connections to the channels. The northwestern most part of the lake near Capoiale is characterized by enrichment in smectite $(\sim 50 \%)$ and kaolinite $(\sim 10 \%)$, while the illite and chlorite abundances are limited. The northern area of the lake is characterized by much lower smectite content $(\sim 10 \%)$, while illite and chlorite represent an average of $79 \%$ of the clay association (Fig. 4a). The southern part of the lake displays the highest illite content ( $54 \%$ ) associated with chlorite (39\%), while kaolinite is present in trace amounts and smectite is absent (Fig. 4a). The same mineralogical association is present in the northeastern most part of the lake, near the Varano channel. The area near the San Francesco River is characterized by a local supply of smectite $(6 \%)$ and kaolinite $(7 \%)$. The smectite/illite ratio varies between 0 and 3.4 (Fig. 4b), with the highest values found near the Capoiale channel and high values in the western part of the lake. The Kübler Index varied between 0.25 and $0.64 \_2 \mathrm{~h}$, reflecting moderate to good crystallinity. Most of the samples plot within the typical anchizone area, suggesting that illite derives from slight to moderate metamorphic rocks (Fig. 4d). The Esquevin Index varied between 0.13 and 0.45, indicating Fe and Mg-rich illite, which is mainly produced through weathering (Fig. 4d). 


\section{Influence of water and sediment characteristics: principal component analysis}

In the PCA applied to the correlation matrix, the first four components are considered as they accounted for ca. $85 \%$ of the total variation (Table 3). With a correlation above 0.7 or below -0.7 , each principal component was correlated to at least three variables (Table 3). The loadings of the first component (PC1) (explaining $44 \%$ of the total variation) are large for all of the metals except $\mathrm{Cu}, \mathrm{Mn}, \mathrm{Mg}$, and $\mathrm{Na}$ (Table 3). $\mathrm{CaCO}_{3}, \mathrm{Ca}$, and $\mathrm{Sr}$ are opposed to the others. The PC1 may represent the terrigenous fraction of the sediment.

The loadings of the second component (PC2, explaining $21 \%$ of the total variation) are large for depth, $\mathrm{Mg}, \mathrm{Na}$, and TOC. This points to the first-order environmental characteristics of depth ( $\mathrm{Na}, \mathrm{Mg}$ ) and organic matter quantity (TOC). The loadings of the third component (PC3, $11 \%$ of the variation) are large for $\mathrm{pH}, \mathrm{ORP}, \mathrm{DO}$, and salinity. ORP, which is associated with a decrease in DO, and salinity are opposed to the two other parameters. PC3 is thus indicative of water characteristics. The fourth and last component (PC4, which accounts for $9 \%$ of the total variation) has large loadings with sediment texture. The clay and silt proportions are opposed to the sand proportions.

Salinity, $\mathrm{S}, \mathrm{Cu}, \mathrm{Mn}$, and $\mathrm{P}$ have no large loadings for any of the principal components.

Communality describes the proportion of the variability of each characteristic that is explained by the PCA model. This shows that the variability of most characteristics is described rather well (Table 3). Only the two variables of S and TOC do not have high communality.

\section{Spatial variability of the variables: geostatistical analysis}

The spatial dependency of the PCA is rather strong despite the various elements of the nugget effect in the variograms (Table 4). The highest spatial dependency is found for PC4 (ca. $46 \%$ ). All of the PCs are modeled with a spherical model. Spherical models suggest a gradual increase of the semivariance as a function of distance up to the range distance from which the spatial variance no longer evolves with increasing distance. This implies that spatial dependency declines at a steady rate with increased distance, and then it does not change. The ranges are $4840 \mathrm{~m}$ for PC4 and up to $15,455 \mathrm{~m}$ for PC2.

Kriged maps of the spatial distribution of the principal components are shown in Fig. 5. The strongest positive values of PC1 are observed all along the eastern border of the lake and extend towards the central part of it (Fig. 5a). The areas with high value of PC1 represent localities with high $\mathrm{Cd}, \mathrm{Cr}, \mathrm{Ni}, \mathrm{Fe}, \mathrm{Mn}, \mathrm{Zn}, \mathrm{Pb}, \mathrm{As}, \mathrm{Co}, \mathrm{K}, \mathrm{La}, \mathrm{Sc}, \mathrm{Ti}, \mathrm{V}, \mathrm{Y}, \mathrm{Zr}$, and Mn, with $\mathrm{P}$ having a lower contribution. This would represent an area with a strong terrigenous 
influence. The distribution corresponds to the major entrance of rivers and drainage into the lake. The effects of water depth and TOC are observed on the map of PC2. The highest scores of PC2 (Fig. 5b) are located on the periphery of the lake, mostly in the northern and eastern parts. These areas correspond to the shallowest depth, while the lowest value corresponds to the highest TOC and the highest depth. The distribution of the PC3 scores shows a clear north-south gradient, with the maximum $\mathrm{pH}$ and DO levels in the southern part and the maximum ORP and salinity in the northern part of the lake (Fig. 5c). The effect of the grain size can be observed in the PC4 map, with the highest proportion of sand in the northern part (connected to the sand bar) and central part of the lake located where there are the highest scores (Fig. 5d), and the highest proportion of silt (with the lowest score value) in the rest of the border of the lake (Fig. 5d).

\section{Spatial variability of benthic fauna}

The meiobenthic assemblages revealed H' values between 0.14 (V34) and 1.28 (V4) (Table 1, Appendix 1 in ESM). The highest H' values were found along the sand bar and near the Capoiale Channel as well as in the southeastern part of the lake (Fig. 6d). The meiobenthic abundance ranged from 175 ind. $10 \mathrm{~cm}-2$ (V18) to 4024 ind. $10 \mathrm{~cm}-2$ (V48), with the highest values located in the southeastern margins of the lake, in connection with the Antonino and San Francesco rivers as well as the Capoiale Channel (Fig. 6c). The meiobenthic density and diversity spatial dependencies were strong (Table 4).

The benthic foraminiferal diversity (H') varied from 1.02 (V13) to 2.27 (V7) (Table 1, Appendix 1 in ESM). The highest $H^{\prime}$ values were encountered in connection with the Capoiale Channel, along the western border, and in the southwestern part of the lake (Fig. 6b). A large northeastern area of the lake had lower diversity values. The foraminiferal density revealed a complex pattern of distribution, with patches of high abundance reaching a maximum in V9 (23.26) (Fig. 6a). The spatial dependency of the foraminiferal diversity and density was strong (Table 4).

\section{Influence of environmental factors on benthic fauna: cross-variogram analysis}

The spatial relationships between faunal distribution (Fig. 6) and the synthetic environmental parameters (Fig. 5) were studied through cross-variogram analyses (Fig. 7). Most cross-variograms are far from perfect correlations: no faunal parameters are entirely controlled by a single environmental group (component). 
The cross-variograms for Lake Varano show a strong negative coregionalization between foraminiferal diversity and synthetic factor 1 (i.e. terrigenous influence) and a negative one, though weaker, with synthetic factor 3 (i.e., water characteristics) but positive, again weaker, with synthetic factor 2 . The coregionalization between meiofaunal diversity and the synthetic factors 1 and 2 are strong and positive. No cross-variograms with foraminiferal and meiofaunal abundances were close to a perfect correlation. These observations suggest that diversities of both foraminifera and meiofauna are influenced by the sea-continent gradient, and that in coastal environments it remains the main factor. Organic matter and depth mainly structure meiofaunal diversity. The negative coregionalization between foraminifera and oxygen and $\mathrm{pH}$ means that these protists are not negatively influenced by the lowest oxygen and $\mathrm{pH}$ levels recorded in the lake and are positively influenced by salinity. These relationships should, however, be regarded with caution as water parameters are only occasional measurements and are not integrated through time.

\section{Discussion}

In most of the papers dealing with the issue of environmental impact on foraminifera and meiobenthos, parameters are tested separately on fauna although these parameters interact within the natural environment. As a consequence, the analysis of the spatial distribution of synthetic factors as a set of variables may be the best approach to environmental monitoring. The present study enabled us to distinguish four orders of influence on benthic fauna among tested parameters. In this coastal environment, the first-order parameter concerns the origin of the sediment (continental vs. marine), the second is a combination of organic matter and water depth, the third is water characteristics, and the fourth-order parameter is related to the sediment grain size.

\section{First-order parameter: continental versus marine sediment}

The first synthetic factor is interpreted as mapping the terrigenous versus the marine influence. The concentration of the analyzed elements shows that the majority of the sediment is from a terrigenous input and reflects the dominant sediment input that comes from the erosion of the eastern, southern, and western coasts. Cadmium and As are exceptions, where over-concentrations with respect to the expected terrigenous input may have another origin. The northern enrichment is probably caused by the relatively larger development of the habitat in the sand bar (compared to the absence of intense activity elsewhere), and could be considered to result from local pollution. However, for the southern part, this enrichment in 
$\mathrm{Cd}$ and As may be artificial, induced by Al-normalization using very low Al concentration (see discussion in Tribovillard et al. 2006). To this end, a more precise investigation of the minerals that comprise the sediment should be carried out. Copper and $\mathrm{Ni}$ are known to be productivity proxies (Tribovillard et al. 2006). However, in the present case, as they are clearly correlated with $\mathrm{Al}, \mathrm{Cu}$ and $\mathrm{Ni}$ do not reflect any influence of productivity and are here considered of terrigenous origin. Copper concentration is particularly high in only one sample and can only be regarded as being so due to high productivity or local pollution. This interpretation of normalization with respect to $\mathrm{Al}$ as a way to underline the natural input is an efficient improvement compared with the simple comparison of the effect rangelow (ER-L) and effect range-median (ER-M) values contained in the United States Environmental Protection Agency's (USEPA) sediment guidelines (Long et al. 1995; Ligero et al. 2002) (sill values are included in Appendix 1 in ESM). Using the guidelines, only $2 \%$ of the samples (1 sample each) are considered to be polluted by $\mathrm{As}, \mathrm{Cd}$, and $\mathrm{Cu}$. This is, however, an underestimation for $\mathrm{Cd}$ and $\mathrm{As}$ because, compared to the theoretical terrigenous input (samples moving away from the $\mathrm{Cd} / \mathrm{Al}=1$ line), a figure of $11 \%(\mathrm{Cd} / \mathrm{Al}>1$ for six samples) is obtained. The opposite situation applies for $\mathrm{Ni}$ as the guidelines distinguish $42 \%$ of polluted samples, whereas $\mathrm{Ni}$ is considered to be a natural terrigenous input (no authigenic enrichment relative to natural background composition as estimated from $\mathrm{Ni} / \mathrm{Al}$ relationships). When compared to the European and Italian sediment quality status guidelines (MSFD 2008, and DM 56/2009), Lake Varano has Cd concentrations exceeding background levels $(60 \%$ of the samples are over $0.6 \mathrm{mg} / \mathrm{kg})$, whereas only $11 \%$ of the samples are considered to be polluted. This is the same with $\mathrm{Cu}(15 \%$ with the reference threshold versus $0 \%$ with the present geochemical approach) and Ni (58 vs. $0 \%$ ). In contrast, the measured concentrations of As are of the order of a background level, whereas five samples are enriched relative to the terrigenous input.

The clay mineral distribution is a second good proxy for assessing the origin of the sediment (Chamley 1989). In Lake Varano, the clay assemblages of the southernmost area reflect the continental supply, whereas the other areas are more influenced by marine inputs. On the scale of a few kilometers, either the clay mineral assemblages or the indices of diagenesis and alteration are slightly different between sectors, reflecting the lithological composition of the different drained watersheds. The northeastern and southern areas have the same clay mineral composition, but the Kübler Index is higher in the southern part of the lake $(\mathrm{IK}=0.33$ vs. $\mathrm{IK}=0.37$ ). As an explanation, the southern area receives water from rivers that principally drain Jurassic limestones (originating from sandy margin deposits with coral 
biofacies, as well as internal platform facies with lagoons and tidal marshes). Meanwhile, the northeastern area receives water that flows over Cretaceous calcarenite, Messinian breccia and calcarenite cropping out on the northwestern side of the Gargano Mountains, as wellas superficial deposits where agriculture land fields were largely developed (Information from Italian National Environment Survey and Monitoring http://www.pcn.minambiente.it/viewer/ with data Corine Land Cover). It should be noted that the drainage of cultivated fields does not significantly change the clay mineralogy and related indices. Some smectite proportions occur in the southeastern area of the lake. This occurrence is correlated to the outlet of the San Francesco River that drains a larger watershed and could provide a wider variety of minerals than other more local and temporal tributaries. Smectite is also observed in the northern area of the lake and might have two sources. The first one could be from the east, with smectite provided by the rivers that flow over Cretaceous limestones (Barresian to Albian), while the second one could be from the west, where an enrichment of smectite is the signature of the marine water input through the Capoiale Channel. Whatever the source, west or east, it originated from marine sediments, either ancient or modern. Indeed, when looking at the clay mineral composition close to the Capoiale Channel, it is characterized by the dominance or a higher occurrence of smectite. This value and the highest values of the smectite/illite ratio suggest a marine contribution of the clay into the lake. This distribution reflects the highest activity of the Capoiale Channel for the entrance of the water to the lake. This finding with the clay mineralogy corroborates the geochemistry observation (enrichment of $\mathrm{Ca}$ and $\mathrm{Sr}$ ). It also confirms the description of Spagnoli et al. (2002), documenting the low salinity distribution all over the lake, with the highest values close to the Capoiale Channel, and hence the limited communication with the sea suggested here.

The first synthetic factor is the only factor that shows a good positive and negative coregionalization with the diversity of meiofauna and foraminifera, respectively. This landsea gradient with all related environmental parameters is the major one on any scale in the Lake Varano. Moreover, the sea impact may have a weaker effect on diversity than the landderived impact. The integration of salinity throughout a broad range of seasonal conditions becomes a key parameter for understanding the fauna distribution in the lake. Salinity is known as an important factor in transitional environments (Hayward et al. 1996, 2004). As the land-derived influence dominates the lake, the sensitive parameter would be more the input of freshwater than the input of salty water. This is reflected by the occurrence of fauna that are typical of a brackish environment (Murray 2006; Scott et al. 2001; Frontalini et al. 
2013, 2014), with the salinity that is generally present throughout the year being $<31$ (Spagnoli et al. 2002).

\section{Second-order parameter: TOC and depth}

The second synthetic factor underlines the influence of depth and TOC. A strong positive coregionalization was calculated between it and the meiofaunal diversity, and a slight one with foraminiferal diversity. TOC is commonly regarded as the key parameter: it represents a source of food that allows fauna to settle and develop. Nevertheless, in certain cases, the concentrations may reach a critical threshold (Murray 2001), and diversity and density may fall (Alve 1995). In Lake Varano, the TOC concentrations often reach 3-5\%, which is high for an aquatic environment. As a consequence, meiofaunal diversity may be more sensitive than foraminiferal diversity and abundance to OM variation. Although TOC enables the quantity of organic matter to be estimated, it provides no information about the quality (labile vs. refractory) thereof (Martins et al. 2015). The ratio of organic carbon to nitrogen $(\mathrm{C} / \mathrm{N})$ is widely used as an indicator of the source of sediment OM (Armynot du Châtelet et al. 2009a, 2011; Maksymowska et al. 2000). Generally, marine and terrestrial OMs have different $\mathrm{C} / \mathrm{N}$ ratios, these being $\sim 5-8$ and $>15$, respectively (Meyers 1997). Most parts of the lake were characterized by $\mathrm{C} / \mathrm{N}$ values between 8 and 15, more likely pointing to terrestrial OM. The lowest $\mathrm{C} / \mathrm{N}$ levels were observed at the periphery, in particular on the southeastern, eastern and northwestern margins of the lake. The northwestern area clearly reflects the input of marine water with marine algae through the Capoiale Channel. The lowest $\mathrm{C} / \mathrm{N}$ ratio on the border of the lake may indicate that these zones are only transitional, and $\mathrm{OM}$ provided by the run-off settles in the deepest central part of the lake and not at the borders. The lowest depths on the periphery have more light and are also more propitious to algal development, thereby lowering the $\mathrm{C} / \mathrm{N}$ ratio. The oxygen-consuming decay of (part of) the relatively high organic matter content may induce the temporary development of anoxic conditions if the oxygen demand exceeds the dissolved oxygen re-supply; such situations are quite common in estuaries or marine embayments ( $\mathrm{Li}$ et al. 2014), even in Lake Varano (Specchiulli et al. 2008 and references therein). Such anoxic episodes are possibly indicated by the high S content $(1.27 \%)$, which may be explained by the occurrence of sulfide ions. These ions may trap and fix (heavy) metals in the form of stable metal sulfides, making them harmless to fauna. On the other hand, during anoxic episodes H2S may be released into the water mass, which might have a negative impact on the fauna. As the sampling campaign 
took place at the beginning of spring, the water was still well oxygenated and the sedimentwater interface was still favorable for faunal development.

\section{Third-order parameter: water characteristics}

The third synthetic factor groups water parameters such as $\mathrm{O}_{2}, \mathrm{pH}$, salinity, and ORP. As these parameters were only timescale as those living fauna. Establishing relationships between these water characteristics and the fauna may be difficult. The synthetic factor shows a clear north-south gradient and could be explained by a sea-continent gradient influence. This factor is negatively coregionalized to foraminiferal diversity, suggesting higher values of this foraminiferal parameter to less confined conditions, namely when the marine influence is stronger.

\section{Fourth-order parameter: sediment size characteristics, influence of sand}

The fourth synthetic gradient clearly reflects the sediment grain size characteristics. No coregionalizations are found between the diversity and density of both foraminifera and meiofauna, and this fourth synthetic factor. However, sand grains may have a mechanical negative effect on juveniles, preventing growth and settlement (Armynot du Châtelet et al. 2009a, b). As described earlier (Alve and Murray 1999), sediment grain size may be a limiting factor when sand proportions increase. In Lake Varano, even if sand fraction is often dominant, sand grains may have no mechanical impact on fauna diversity and distribution because of slow currents. In contrast to Specchiulli et al. (2010) (sampling in 2007) and Molinaroli et al. (2014) (sampling in 2002), our sediments were dominated by silt (49\%) and sand (50\%) instead of mainly being composed of silt (67 and $18 \%$ in Specchiulli et al. 2010, and 64 and $14 \%$ in Molinaroli et al. 2014). This discrepancy probably results from the sampling as Specchiulli et al. (2010) and Molinaroli et al. (2014) sampled sediment with a depth of 15 and $10 \mathrm{~cm}$, respectively, whereas our sampling was for sediment with a depth of only $2 \mathrm{~cm}$. Moreover, both these papers relied on a Sedigraph 5100 Micrometrics for the smaller fraction after sieving. Both sieving and use of an X-ray beam may produce different results to our protocol which used a laser but no preliminary sieving. Both sampling and differences in the analytical procedures could have led to this shift in the mean grain size. This difference was also correctly pointed out by Molinaroli et al. (2014) who explained that a different analytical procedure in sample treatment caused by possible flocculation might have led to an overestimation of the coarse fractions. 


\section{Conclusion}

In areas with very low pollution such as Lake Varano, an input should be carried out when describing the ecological status of a coastal environment. The Lake Varano ecosystem is predominantly influenced by terrigenous inputs (first-order parameter). The clastic fractions of the sediments supply a large range of trace elements, sometimes in relatively high concentrations. Under such circumstances, despite occasionally exceeding the threshold limits, the trace element pollution can generally be ruled out. In the present case, only five samples yielded an enrichment of $\mathrm{Cd}$ and this could be interpreted as the echo of low-tomoderate pollution induced by the human activity developing on the sand bar. The organic content combined with depth is the second key parameter. In Lake Varano, the organic content is high and may be conducive to seasonal eutrophication. As a third-order parameter, though only analyzed once, oxygen, ORP, salinity, and $\mathrm{pH}$ gradients may show that foraminiferal diversity is positively influenced by more saline conditions. The fourth synthetic parameter is the sediment size. In the present study, no spatial interaction is underlined with the distribution of the fauna. To conclude, this paper illustrates the interest in and need to conduct a detailed, integrated, sedimentological study of a site prior to any examination of its ecological status (possible occurrences of sources of pollution).

\section{Acknowledgments}

We warmly thank Romain Abraham and Marion Delattre for technical analysis. The authors are grateful to the three anonymous reviewers as well as the co-editor in chief Prof. Olaf Kolditz for the thorough suggestions and revisions.

\section{References}

Alve E (1995) Benthic foraminiferal responses to estuarine pollution: a review. J Foraminifer Res 25:190-203

Alve E, Murray JW (1999) Marginal marine environments of the Skagerrak and Kattegat: a baseline study of living (stained) benthic foraminiferal ecology. Palaeogeogr Palaeoclimatol Palaeoecol 146:171-193

Armynot du Châtelet E, Bout-Roumazeilles V, Riboulleau A, Trentesaux A (2009a) Sediment (grain size and clay mineralogy) and organic matter quality control on living benthic foraminifera. Rev Micropaleontol 52:75-84

Armynot du Châtelet E, Degré D, Sauriau P-G, Debenay J-P (2009b) Distribution of living benthic foraminifera in relation with environmental variables within the Aiguillon cove 
(Atlantic coast, France): improving knowledge for paleoecological interpretation. Bull Soc Geol France 180:131-144

Armynot du Châtelet E, Gebhardt K, Langer MR (2011) Coastal pollution monitoring: foraminifera as tracers of environmental perturbation in the port of Boulogne-sur-Mer (Northern France). Neues Jahrbuch für Geologie und Palaëontologie-Abhandlungen 262:91116

Armynot du Châtelet E, Frontalini F, Guillot F, Recourt P, Ventalon S (2013) Surface analysis of agglutinated benthic foraminifera through ESEM-EDS and Raman analyses: an expeditious approach for tracing mineral diversity. Mar Micropaleontol 105(18-29):18-29

Barnes RSK (1991) European estuaries and lagoons: a personal overview of problems and possibilities for conservation and management. Aquat Conserv 1:79-87

Baxter SJ, Oliver JD (2005) The spatial prediction of soil mineral $\mathrm{N}$ and potentially available $\mathrm{N}$ using elevation. Geoderma 128:325-339

Belmonte G, Scirocco T, Denitto F (2011) Zooplankton composition in Lake Varano (Adriatic Sea coast, Italy). Ital J Zool 78:370-378

Bertazzon S, Micheletti C, Critto A, Marcomini A (2006) Spatial analysis in ecological risk assessment: pollutant bioaccumulation in clams Tapes philipinarum in the Venetian lagoon (Italy). Comput Environ Urban Syst 30:880-904

Bout-Roumazeilles V, Cortijo E, Labeyrie L, Debrabant P (1999) Clay mineral evidence of nepheloid layer contribution to the Heinrich layers in the Northwest Atlantic. Palaeogeogr Palaeoclimateol Palaeoecol 146:211-228

Breber P, Scirocco T (1998) Open-sea mussel farming in Southern Italy. Eastfish Magazine $22: 36-38$

Brindley GW, Brown G (1980) Crystal structures of clay minerals and their X-ray identification. Mineralogical Society, London

Carroll ZL, Oliver MA (2005) Exploring the spatial relations between soil physical properties and apparent electrical conductivity. Geoderma 128:354-374

Chamley H (1989) Clay sedimentology. Spinger, Berlin

Dauvin J-C, Ruellet T (2009) The estuarine quality paradox: is it possible to define an ecological quality status for specific modified and naturally stressed estuarine ecosystems? Mar Pollut Bull 59:38-47

DM 56/2009, The Italian guide line DM 56/2009: Decreto del Ministero dell'Ambiente, e della Tutela del Territorio e del Mare, n_ 56, 14 Aprile 2009. Regolamento recante «Criteri tecnici per il monitoraggio dei corpi idrici e l'identificazione delle condizioni di riferimento 
per la modifica delle norme tecniche del decreto legislativo 3 aprile 2006, n. 152, recante Norme in materia ambientale, predisposto ai sensi dell'articolo 75 , comma 3 , del decreto legislativo medesimo». (09G0065) (GU Serie Generale n.124 del 30-5-2009—Suppl. Ordinario n. 83)

Esquevin J (1969) Influence de la composition chimique des argiles sur la cristallinité. Bull Centre Rech Pau-SNPA 3:147-154

Frontalini F, Coccioni R (2011) Benthic foraminifera as bioindicators of pollution: a review of Italian research over the last three decades. Rev Micropaléontol 54:115-127

Frontalini F, Armynot du Châtelet E, Debenay J-P, Coccioni R, Bancalá G (2011a) Benthic foraminifera in coastal lagoons: distributional patterns and biomonitoring implications. In: Friedman AG (ed) Lagoons: biology, management and environmental impact. Nova Science Publishers Inc., New York, pp 39-72

Frontalini F, Semprucci F, Coccioni R, Balsamo M, Bittoni P, Covazzi-Harriage A (2011b) On the quantitative distribution and community structure of the meio and macrofaunal communities in the coastal area of the Central Adriatic Sea (Italy). Environ Monit Assess 180:325-344. doi:10.1007/s10661-010-1791-y

Frontalini F, Margaritelli G, Francescangeli F, Rettori R, Armynot du Châtelet E, Coccioni R (2013) Benthic foraminiferal assemblages and biotopes of a coastal lake: the case study of Lake Varano (southern Italy). Acta Protozool 52:147-160

Frontalini F, Semprucci F, Armynot du Châtelet E, Francescangeli F, Margaritelli G, Rettori R, Spagnoli F, Balsamo M, Coccioni R (2014) Biodiversity trends of the meiofaunal and foraminiferal assemblages of Lake Varano (southern Italy). Proc Biol Soc Wash 127:7-22

Hayward BW, Grenfell H, Cairns G, Smith A (1996) Environmental controls on benthic foraminiferal and thecamoebian associations in a New Zealand tidal inlet. J Foraminifer Res 26:150-171

Hayward BW, Scott GH, Grenfell HR, Carter R, Lipps JH (2004) Estimation of tidal elevation and salinity histories of sheltered harbours and estuaries using benthic foraminifera. Holocene 14:218-232

Ligero RA, Barbera M, Casas-Ruiz M, Sales D, Lopez-Aguayo F (2002) Dating of marine sediments and time evolution of heavy metal concentration in the Bay of Cadiz, Spain. Environ Pollut 118:97-108

Long ER, MacDonald DD, Smith SL, Calder FD (1995) Incidence of adverse biological effects within ranges of chemical concentrations in marine and estuarine sediments. Environ Manag 19:81-97 
Maksymowska D, Richard P, Piekarek-Jankowska HRP (2000) Chemical and isotopic composition of the organic matter sources in the Gulf of Gdansk (Southern Baltic Sea). Estuar Coast Shelf Sci 51:585-598

Manzari C, Fosso B, Marzano M, Annese A, Caprioli R, D’Erchia AM, Intranuovo M, Gissi C, Santamaria M, Picardi E, Sgaramella G, Scorrano S, Piraino S, Stabili L, Pesole G (2015) The influence of invasive jellyfish blooms on the aquatic microbiome in a coastal lagoon (Varano, SE Italy) detected by an Illumina-based deep sequencing strategy. Biol Invasions 17:923-940

Martins MVA, Silva F, Laut LLM, Frontalini F, Clemente IMMM, Miranda P, Figueira R, Sousa SHM, Dias JMA (2015) Response of benthic foraminifera to organic matter quantity and quality and bioavailable concentrations of metals in Aveiro lagoon (Portugal). PLoS One. doi:10.1371/journal.pone.0118077

Marzano CN, Scalera Liaci L, Fianchini A, Gravina F, Mercurio M, Corriero G (2003) Distribution, persistence and change in the macrobenthos of the lagoon of Lesina (Apulia, southern Adriatic Sea). Oceanol Acta 26:57-66

Meyers PA (1997) Organic geochemical proxies of paleoceanographic, paleolimnologic, and paleoclimatic processes. Org Geochem 27:213-250

Millet B, Guelorget O (1994) Spatial and seasonal variability in the relationships between benthic communities and physical environment in a lagoon ecosystem. Mar Ecol Prog Ser 108:161-174

Molinaroli E, Sarretta A, Ferrarin C, Masiero E, Specchiulli A, Guerzoni S (2014) Sediment grain size and hydrodynamics in Mediterranean coastal lagoons: integrated classification of abiotic parameters. J Earth Syst Sci 123:1097-1114

MSFD (2008) Directive 2008/56/EC of the European Parliament and of the Council of 17 June 2008 establishing a framework for community action in the field of marine environmental policy (marine strategy framework directive)

Murray JW (2001) The niche of benthic foraminifera, critical thresholds and proxies. Mar Micropaleontol 41:1-7

Murray JW (2006) Ecology and applications of benthic foraminifera. Cambridge University Press, Cambridge

Nixon S (1988) Physical energy inputs and the comparative ecology of lake and marine ecosystems. Limnol Oceanogr 33:1005-1025

Petschick R (1997) Powder diffraction software. MacDiff. Freeware: http://www.geol-pal.unifrankfurt.de/Staff/Homepages/Petschick/ classicsoftware.html\#MacDiff 
Polemio M, Di Cagno M, Virga R (2000) Le acque sotterranee del Gargano: risorse idriche integrative e di emergenza. Acque Sotterranee 68:41-58

Scott DB, Medioli FS, Schafer CT (2001) Monitoring in coastal environments using foraminifera and thecamoebian indicators. Cambridge University Press, New York

Semprucci F, Moreno M, Sbrocca C, Rocchi M, Albertelli G, Balsamo M (2013) The nematode assemblage as a tool for the assessment of marine ecological quality status: a casestudy in the Central Adriatic Sea. Mediterr Mar Sci 14:48-57

Semprucci F, Balsamo M, Frontalini F (2014) The nematode assemblage of a coastal lagoon (Lake Varano, southern Italy): ecology and biodiversity patterns. Sci Mar 78:579-588

Semprucci F, Frontalini F, Sbrocca C, Armynot du Châtelet E, Bout- Roumazeilles V, Coccioni R, Balsamo M (2015) Meiobenthos and free-living nematodes as tools for the biomonitoring environments affected by riverine impact. Environ Monit Assess 187:1-19

Spagnoli F, Specchiulli A, Scirocco T, Carapella G, Villani P, Casolino G, Schiavione P, Franchi M (2002) The Lago di Varano: hydrologic characteristics and sediment composition.

Mar Ecol 23:384-394

Specchiulli A, Focardi S, Renzi M, Scirocco T, Cilenti L, Breber P, Bastianoni S (2008) Environmental heterogeneity patterns and assessment of trophic levels in two Mediterranean lagoons: orbetello and Varano, Italy. Sci Total Environ 402:285-298

Specchiulli A, Renzi M, Scirocco T, Cilenti L, Florio M, Breber P, Focardi S, Bastianoni S (2010) Comparative study based on sediment characteristics and macrobenthic communities in two Italian lagoons. Environ Monit Assess 160:237-256

Tribovillard N, Algeo T, Lyons TW, Riboulleau A (2006) Trace metals as paleoredox and paleoproductivity proxies: an update. Chem Geol 232:12-32

Wackernagel H (1989) Description of a computer program for analysing multivariate spatially distributed data. Comput Geosci 15:593-598

Wackernagel H (2003) Multivariate geostatistics: an introduction with applications, 3rd edn. Springer, Berlin

Webster R, Oliver MA (1990) Statistical methods in soil and land resource survey. Oxford University Press, Oxford

Webster R, Oliver MA (2001) Geostatistics for environmental scientists. Wiley, Chichester Weindorf DC, Zhu Y (2010) Spatial variability of soil properties at Capulin Volcano, New Mexico, USA: implications for sampling strategy. Pedosphere 20:185-197

Xl Li, Shi HM, Xia H-Y, Zhou Y-P, Qiu YW (2014) Seasonal hypoxia and its potential forming mechanisms in the Mirs Bay, the Northern South China Sea. Cont Shelf Res 80:1-7 


\section{Figure captions}

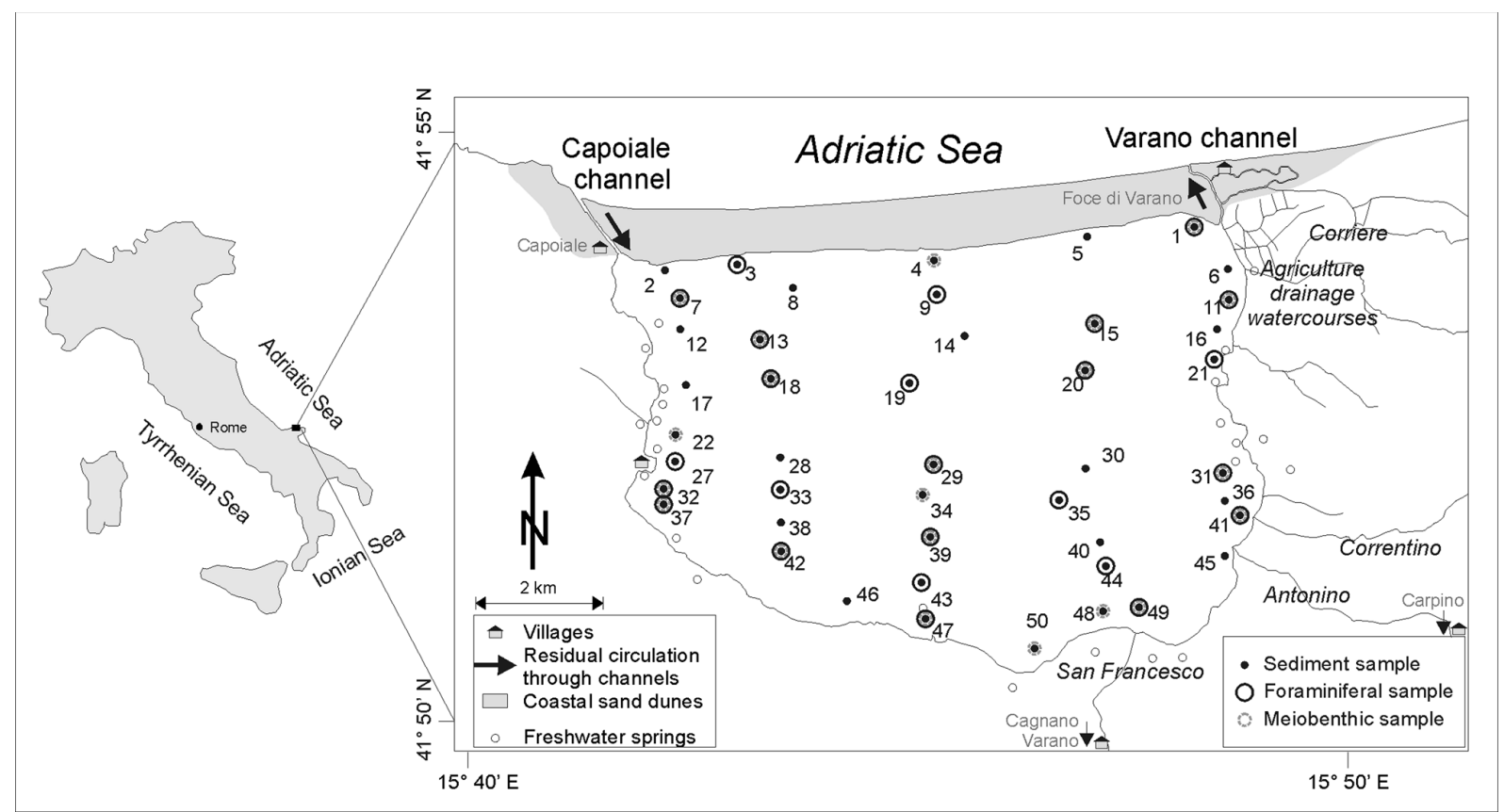

Fig. 1 Location map of the study area with sampling stations (sediment, foraminifera and meiobenthos). The main tributaries and villages are indicated 

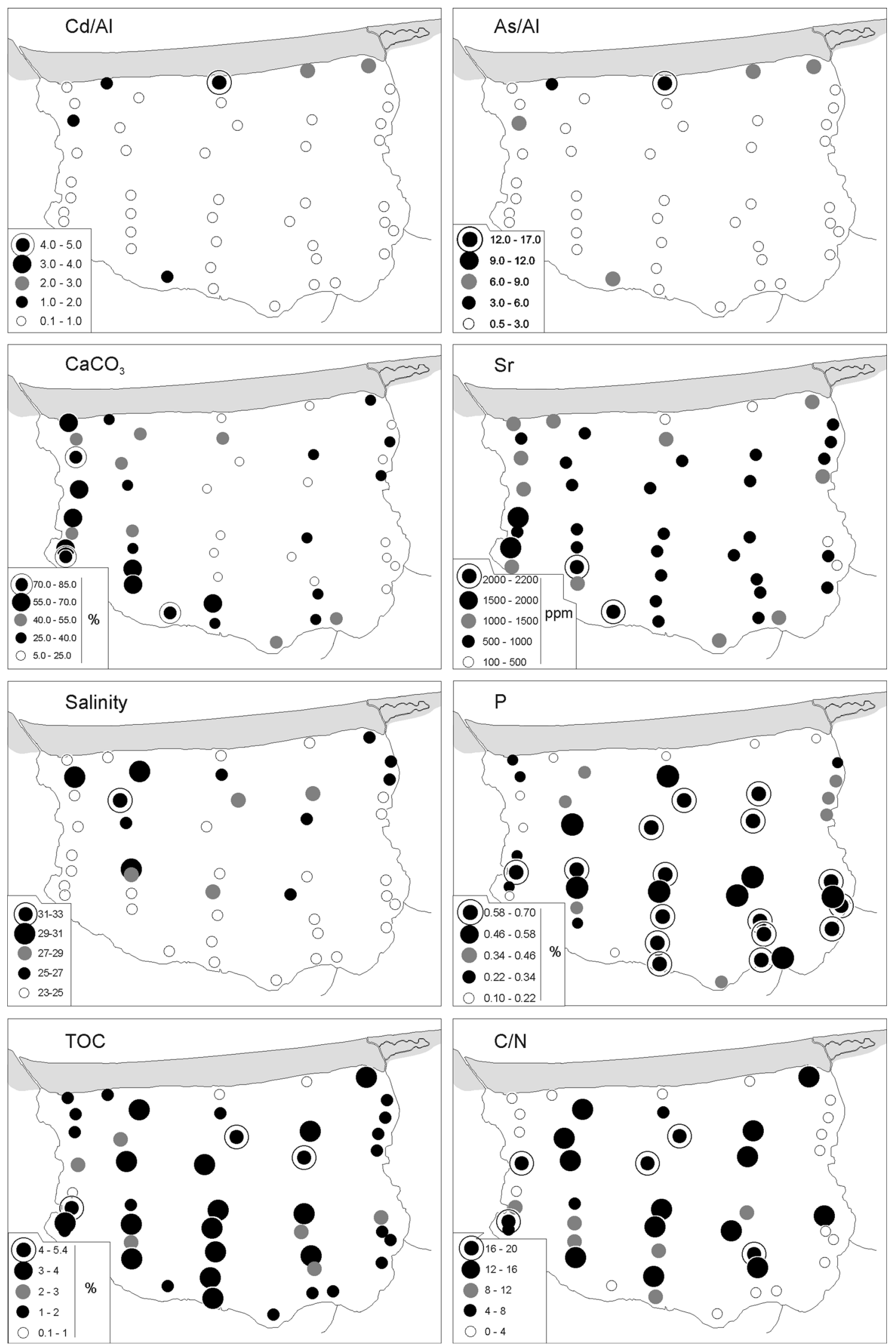

Fig. 2 Geochemical maps for $\mathrm{Cd} / \mathrm{Al}, \mathrm{As} / \mathrm{Al}, \mathrm{CaCO}_{3}$, Sr, Salinity, P, TOC and C/N 


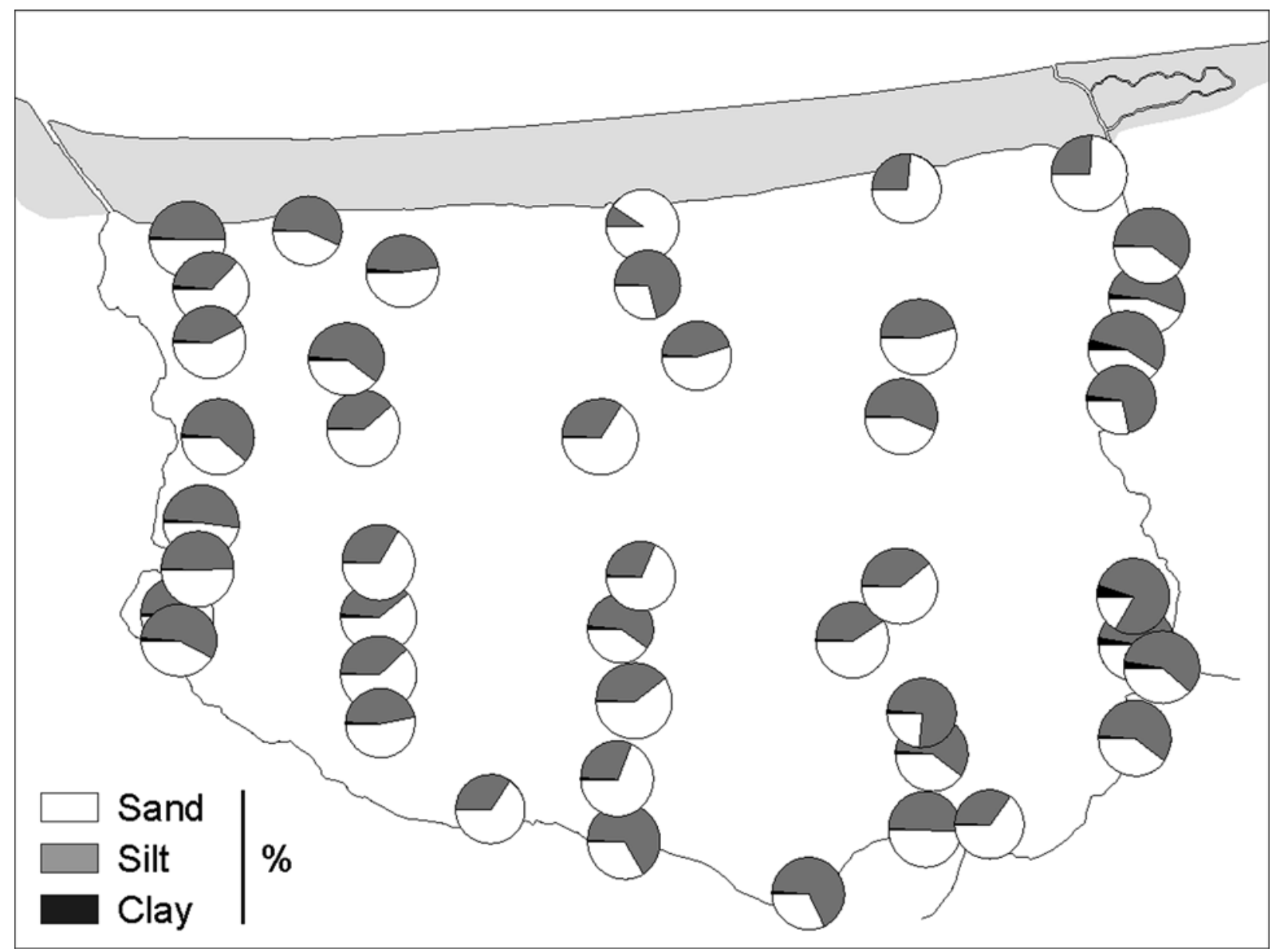

Fig. 3 Sediment grain size fractions (sand, silt, clay) 


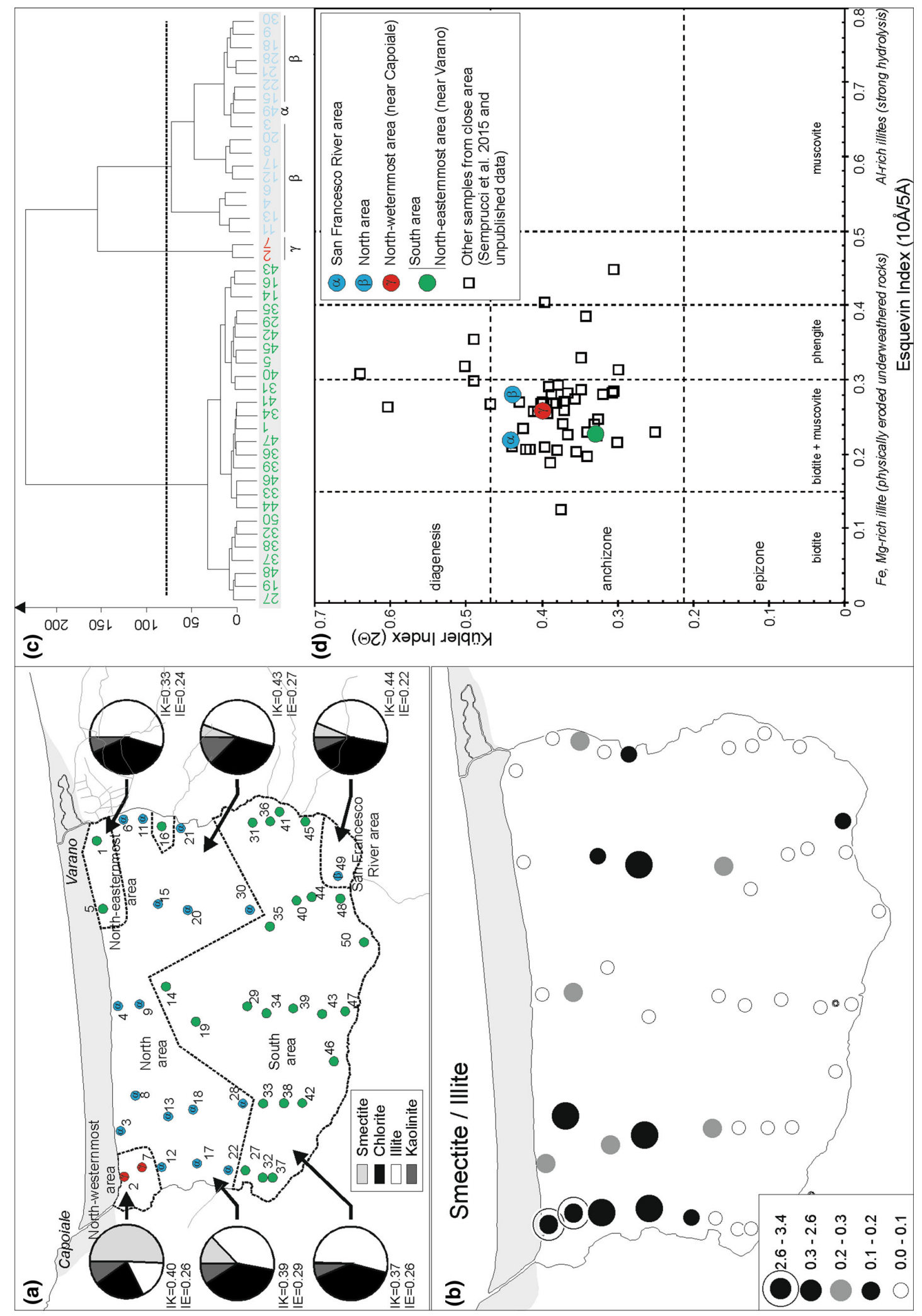

Fig. 4 Clay mineralogy: a Clay mineral distribution. The color of the point refer to the cluster groups (4c). General composition of clay is provided as pie diagram and Esquevin (IE) and Kübler (IK) indexes are provided; b Smectite/Illite map; c cluster dendrogram based on the clay mineral proportion. Groups of samples are provided; d Diagenesis versus alteration diagram (Kübler vs. Esquevin indexes) 
(a) Synthetic factor 1

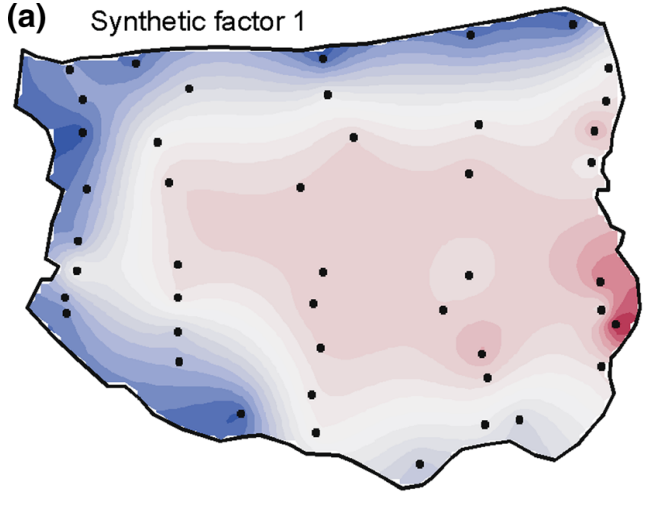

(c) Synthetic factor 3

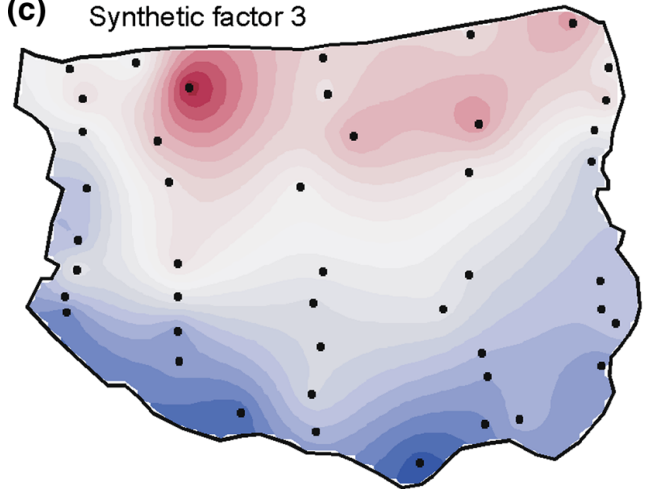

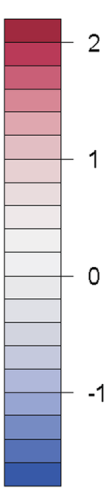

(b) Synthetic factor 2
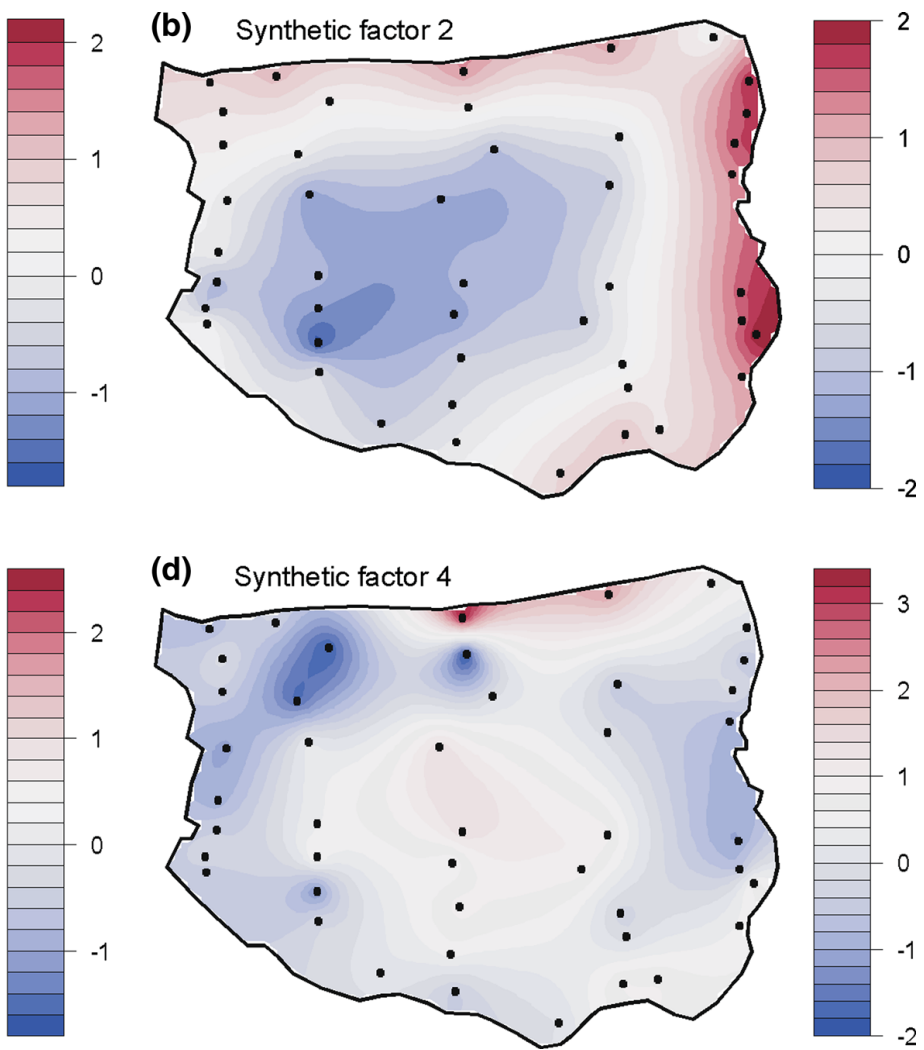

Fig. 5 Maps of the four synthetic factors extracted from the PCA based on the correlation matrix 
(a) Foraminiferal density $(\mathrm{n} / \mathrm{g})$

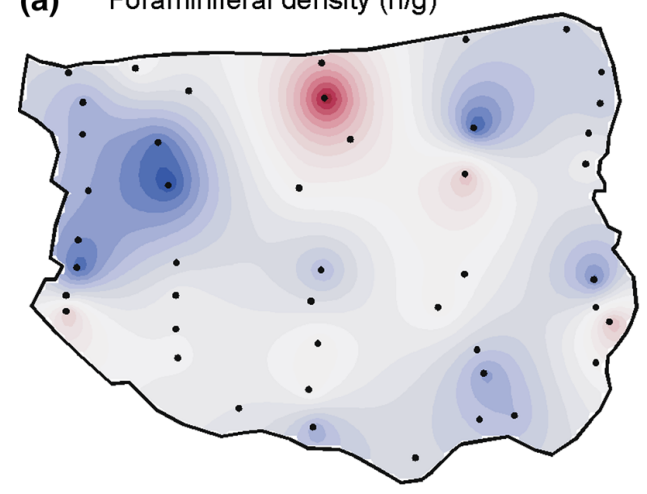

(c) Meiobenthic abundance (ind $10 \mathrm{~cm}^{-2}$ )
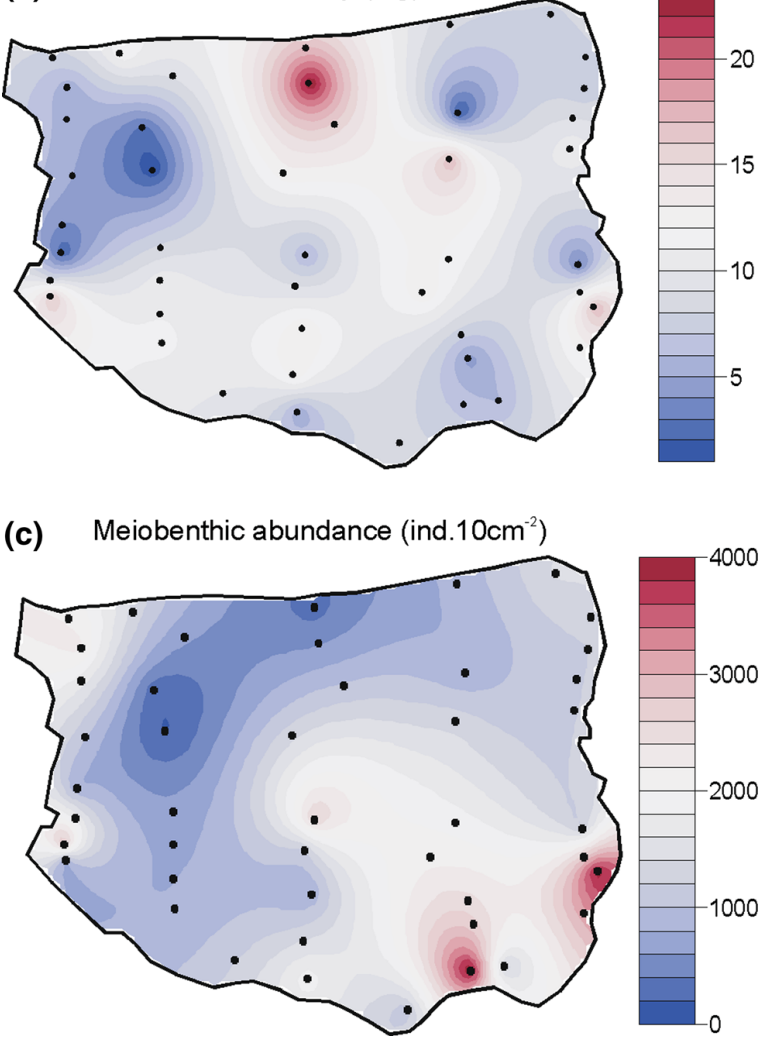

(b) Foraminiferal diversity $\left(\mathrm{H}^{\prime}\right)$

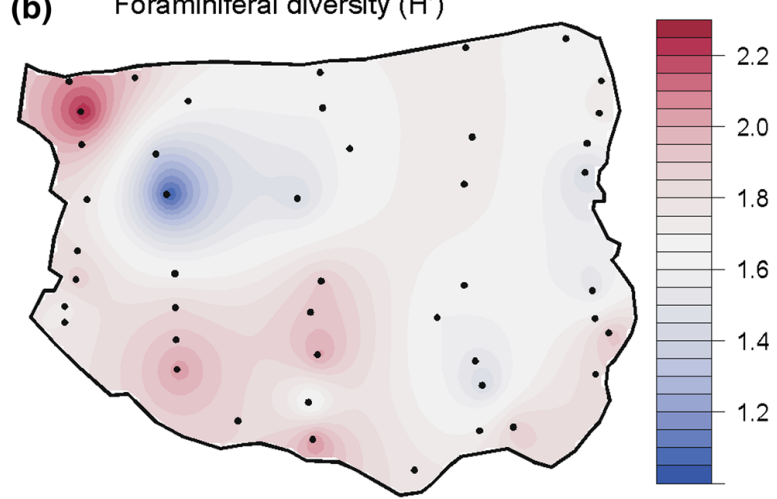

(d) Meiofauna diversity $\left(\mathrm{H}^{\prime}\right)$

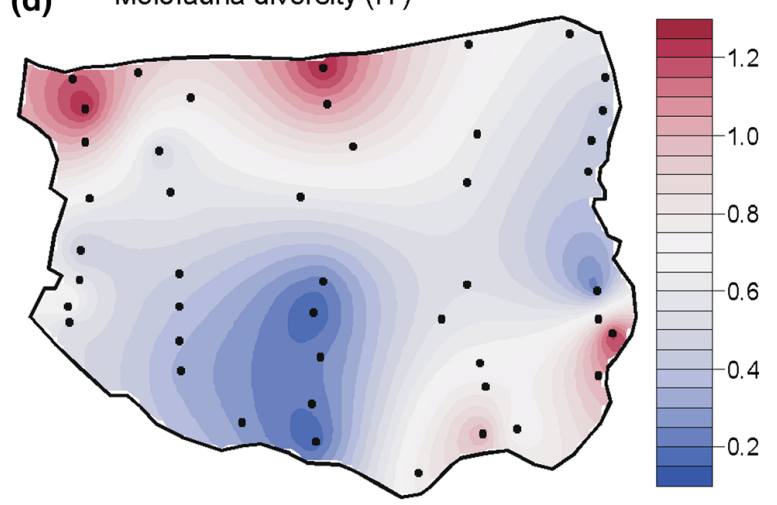

Fig. 6 Maps of the fauna: a Foraminiferal density (number/g); b Foraminiferal diversity ( $\left.\mathrm{H}^{\prime}\right)$; c Meiobenthic abundance (number/10 cm2); d Meiobenthic diversity ( $\left.\mathrm{H}^{\prime}\right)$ 

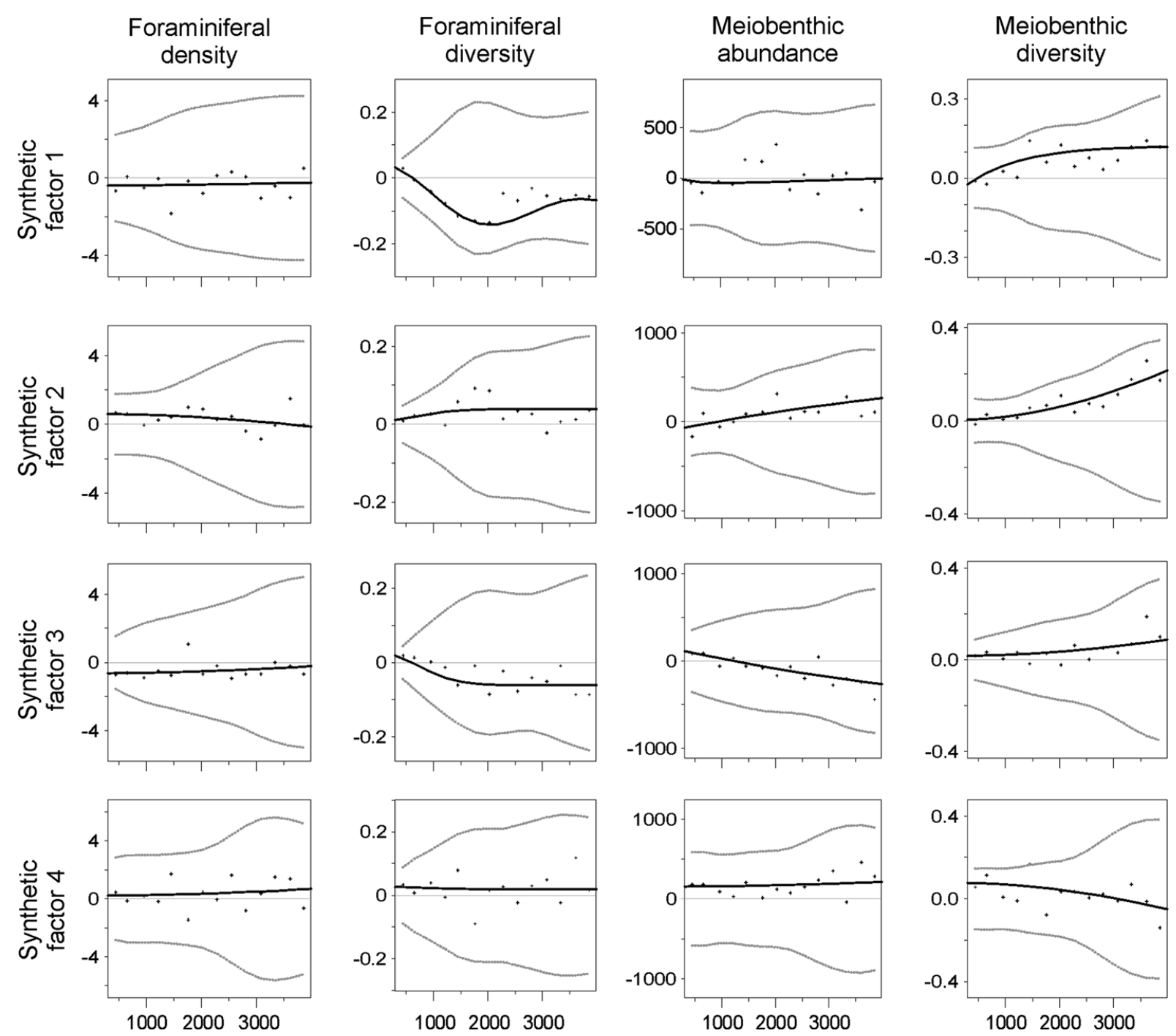

Fig. 7 Cross-variogram biplot between the four synthetic factors and the foraminiferal and meiobenthic diversity and density. It includes the experimental cross-variogram (crosses), the cross-variogram model (bold line) and the bounds of the hull of perfect positive and negative correlation (dotted lines) 
Table 1 Mean, standard deviation (SD), minimum (min), maximum (max) and median values of the physico-chemical, geochemical and faunal parameters

\begin{tabular}{|c|c|c|c|c|c|}
\hline Parameters & Mean & SD & Min & $\operatorname{Max}$ & Median \\
\hline Depth (m) & 3.0 & 0.8 & 1.0 & 4.2 & 3.1 \\
\hline $\mathrm{pH}$ & 7.8 & 0.1 & 7.4 & 8.0 & 7.9 \\
\hline Salinity & 25.3 & 2.1 & 23.0 & 31.9 & 24.3 \\
\hline ORP & 204.8 & 44.0 & 164.0 & 286.0 & 188.0 \\
\hline DO (mg/l) & 9.1 & 2.0 & 2.7 & 15.2 & 9.1 \\
\hline Clay (\%) & 1.1 & 0.9 & 0.1 & 4.8 & 0.9 \\
\hline Silt (\%) & 48.7 & 14.8 & 9.3 & 79.0 & 48.0 \\
\hline Sand $(\%)$ & 50.2 & 15.4 & 16.2 & 90.5 & 50.5 \\
\hline Smectite (\%) & 6.1 & 11.2 & 0.0 & 52.2 & 0.0 \\
\hline Illite (\%) & 48.4 & 9.6 & 15.4 & 59.1 & 51.8 \\
\hline Chlorite (\%) & 37.1 & 5.7 & 21.8 & 45.0 & 38.5 \\
\hline Kaolinite (\%) & 7.6 & 39 & 4.1 & 23.1 & 6.5 \\
\hline Kubler & 0.4 & 0.1 & 0.3 & 0.6 & 0.4 \\
\hline Esquivin & 0.3 & 0.1 & 0.1 & 0.5 & 0.3 \\
\hline $\mathrm{CaCO}_{3}(\%)$ & 37.2 & 19.4 & 9.5 & 81.0 & 30.8 \\
\hline Nitrogen (\%) & 0.3 & 0.1 & 0.2 & 0.4 & 0.3 \\
\hline Sulfur $(\%)$ & 1.3 & 0.3 & 0.9 & 2.0 & 1.3 \\
\hline Carbon $(\%)$ & 6.9 & 2.4 & 1.3 & 11.5 & 6.6 \\
\hline Hydrogen (\%) & 0.9 & 0.3 & 0.1 & 1.3 & 1.0 \\
\hline TOC $(\%)$ & 2.5 & 1.2 & 0.2 & 5.4 & 2.6 \\
\hline $\mathrm{C} / \mathrm{N}$ ratio & 13.0 & 3.3 & 5.7 & 18.9 & 13.0 \\
\hline $\mathrm{Cd}$ (ppm) & 0.7 & 0.2 & 0.5 & 1.2 & 0.7 \\
\hline $\mathrm{Cu}$ (ppm) & 16.7 & 9.3 & 1.0 & 51.0 & 18.0 \\
\hline Mn (ppm) & 370.8 & 142.4 & 115.0 & 623.0 & 404.0 \\
\hline $\mathrm{Ni}$ (ppm) & 17.3 & 10.0 & 1.0 & 39.0 & 20.0 \\
\hline $\mathrm{Pb}(\mathrm{ppm})$ & 19.1 & 10.3 & 2.0 & 35.0 & 22.0 \\
\hline $\mathrm{Zn}(\mathrm{ppm})$ & 45.8 & 245 & 4.0 & 101.0 & 50.0 \\
\hline $\mathrm{Al}(\%)$ & 2.5 & 15 & 0.1 & 5.6 & 3.1 \\
\hline As (ppm) & 3.9 & 2.2 & 2.0 & 12.0 & 4.0 \\
\hline $\mathrm{Ca}(\%)$ & 11.3 & 4.7 & 3.6 & 26.2 & 9.9 \\
\hline Co (ppm) & 5.2 & 2.9 & 1.0 & 12.0 & 6.0 \\
\hline $\mathrm{Cr}$ (ppm) & 23.8 & 12.8 & 2.0 & 49.0 & 28.0 \\
\hline $\mathrm{Fe}(\%)$ & 1.7 & 0.9 & 0.1 & 3.5 & 2.0 \\
\hline K (\%) & 0.4 & 0.2 & 0.0 & 0.7 & 0.5 \\
\hline $\mathrm{La}$ (ppm) & 25.2 & 12.9 & 10.0 & 62.0 & 27.0 \\
\hline Mg (\%) & 0.6 & 0.2 & 0.2 & 0.9 & 0.7 \\
\hline $\mathrm{Na}(\%)$ & 1.3 & 0.5 & 0.3 & 2.2 & 1.4 \\
\hline $\mathrm{P}(\%)$ & 0.0 & 0.0 & 0.0 & 0.1 & 0.1 \\
\hline $\mathrm{Sc}$ (ppm) & 3.4 & 1.8 & 1.0 & 8.0 & 4.0 \\
\hline $\mathrm{Sr}$ (ppm) & 905.6 & 418.0 & 136.0 & 2180.0 & 746.0 \\
\hline $\mathrm{Ti}$ (ppm) & 0.1 & 0.0 & 0.0 & 0.1 & 0.1 \\
\hline V (ppm) & 35.2 & 19.1 & 2.0 & 83.0 & 42.0 \\
\hline $\mathrm{Y}(\mathrm{ppm})$ & 14.1 & 75 & 3.0 & 37.0 & 15.0 \\
\hline $\mathrm{Zr}$ (ppm) & 14.5 & 11.0 & 1.0 & 42.0 & 13.0 \\
\hline Meiofaunal diversity $\left(\mathrm{H}^{\prime}\right)$ & 0.6 & 0.4 & 0.1 & 1.3 & 0.6 \\
\hline Meiofaunal abundance ind. $10 \mathrm{~cm}^{-2}$ & 1475.0 & 1086.4 & 175.0 & 4024.0 & 1185.0 \\
\hline Foraminiferal diversity $\left(\mathrm{H}^{\prime}\right)$ & 1.7 & 0.3 & 1.0 & 2.3 & 1.7 \\
\hline Foraminiferal density (n/g) & 9.2 & 5.8 & 1.0 & 23.3 & 8.4 \\
\hline
\end{tabular}



Table 2 Correlation between chemical element and $\mathrm{Al}$ and $\mathrm{Sr}$

\begin{tabular}{lcc}
\hline $\mathrm{Ratio}$ & $r=$ Correlation coefficient & Cor $p$ value \\
\hline $\mathrm{Cd} / \mathrm{Al}$ & 0.88 & $1.33 \mathrm{e}-15$ \\
$\mathrm{Cu} / \mathrm{Al}$ & 0.73 & $1.71 \mathrm{e}-08$ \\
$\mathrm{Cu} / \mathrm{Al}$ & 0.95 & $<2.2 \mathrm{e}-16$ \\
$\mathrm{Mr} / \mathrm{Al}$ & 0.69 & $1.57 \mathrm{e}-07$ \\
$\mathrm{Ni} / \mathrm{Al}$ & 0.98 & $<2.2 \mathrm{e}-16$ \\
$\mathrm{~Pb} / \mathrm{Al}$ & 0.97 & $<2.2 \mathrm{e}-16$ \\
$\mathrm{Zn} / \mathrm{Al}$ & 0.98 & $<2.2 \mathrm{e}-16$ \\
$\mathrm{As} / \mathrm{Al}$ & 0.77 & $6.69 \mathrm{e}-10$ \\
$\mathrm{Ca} / \mathrm{Al}$ & -0.69 & $1.73 \mathrm{e}-07$ \\
$\mathrm{Co} / \mathrm{Al}$ & 0.98 & $<2.2 \mathrm{e}-16$ \\
$\mathrm{Cr} / \mathrm{Al}$ & 0.99 & $<2.2 \mathrm{e}-16$ \\
$\mathrm{Fe} / \mathrm{Al}$ & 0.99 & $<2.2 \mathrm{e}-16$ \\
$\mathrm{~K} / \mathrm{Al}$ & 0.98 & $<2.2 \mathrm{e}-16$ \\
$\mathrm{La} / \mathrm{Al}$ & 0.91 & $<2.2 \mathrm{e}-16$ \\
$\mathrm{Mg} / \mathrm{Al}$ & 0.79 & $8.50 \mathrm{e}-11$ \\
$\mathrm{Na} / \mathrm{Al}$ & 0.45 & $2.05 \mathrm{e}-03$ \\
$\mathrm{P} / \mathrm{Al}$ & 0.82 & $8.89 \mathrm{e}-12$ \\
$\mathrm{Sc} / \mathrm{Al}$ & 0.97 & $<2.2 \mathrm{e}-16$ \\
$\mathrm{Sr} / \mathrm{Al}$ & -0.62 & $5.58 \mathrm{e}-06$ \\
$\mathrm{Ti} / \mathrm{Al}$ & 0.92 & $<2.2 \mathrm{e}-16$ \\
$\mathrm{~V} / \mathrm{Al}$ & 0.99 & $<2.2 \mathrm{e}-16$ \\
$\mathrm{Y} / \mathrm{Al}$ & 0.95 & $<2.2 \mathrm{e}-16$ \\
$\mathrm{Zr} / \mathrm{Al}$ & 0.87 & $4.6629 \mathrm{E}-15$ \\
$\mathrm{Sulfur} / \mathrm{Al}$ & 0.28 & 0.05840865 \\
$\mathrm{Cmin} / \mathrm{Al}$ & 0.87 & $9.77 \mathrm{E}-15$ \\
$\mathrm{Ca} / \mathrm{Sr}$ & 0.96 & $<2.2 \mathrm{e}-16$ \\
\hline & & \\
\hline & &
\end{tabular}

${ }^{a}$ Designate $\mathrm{Cu}$ when removing one outlier 
Table 3 Correlation between the principal component and the variable

\begin{tabular}{|c|c|c|c|c|c|}
\hline & $\mathrm{PC} 1$ & $\mathrm{PC} 2$ & $\mathrm{PC} 3$ & PC4 & Communality \\
\hline Depth & 0.3 & 0.85 & 0.01 & 0.08 & 0.82 \\
\hline $\mathrm{pH}$ & 0.12 & 0.05 & 0.94 & -0.11 & 0.9 \\
\hline Salinity & 0.14 & 0.53 & -0.65 & -0.13 & 0.74 \\
\hline ORP & -0.13 & -0.25 & -0.83 & -0.24 & 0.82 \\
\hline DO & 0.14 & 0.27 & 0.78 & -0.24 & 0.75 \\
\hline Clay & 0.5 & -0.13 & -0.06 & 0.69 & 0.74 \\
\hline Silt & 0.2 & 0 & -0.02 & 0.88 & 0.82 \\
\hline Sand & -0.22 & 0.01 & 0.02 & -0.89 & 0.84 \\
\hline $\mathrm{CaCO}_{3}$ & -0.82 & 0.01 & 0.09 & 0.25 & 0.75 \\
\hline S & 0.15 & 0.61 & -0.01 & -0.32 & 0.49 \\
\hline TOC & 0.08 & 0.82 & 0.04 & -0.09 & 0.68 \\
\hline $\mathrm{Cd}$ & 0.79 & 0.47 & 0.17 & -0.01 & 0.87 \\
\hline $\mathrm{Cu}$ & 0.45 & 0.58 & 0.12 & 0.29 & 0.64 \\
\hline Mn & 0.59 & 0.42 & 0.19 & 0.13 & 0.58 \\
\hline $\mathrm{Ni}$ & 0.83 & 0.49 & 0.09 & 0.18 & 0.98 \\
\hline $\mathrm{Pb}$ & 0.79 & 0.53 & 0.17 & 0.16 & 0.96 \\
\hline Zn & 0.83 & 0.49 & 0.12 & 0.21 & 0.98 \\
\hline Al & 0.86 & 0.4 & 0.13 & 0.26 & 0.99 \\
\hline As & 0.82 & 0.08 & -0.08 & 0.35 & 0.81 \\
\hline $\mathrm{Ca}$ & -0.89 & -0.01 & 0.08 & 0.25 & 0.87 \\
\hline Co & 0.88 & 0.35 & 0.13 & 0.25 & 0.98 \\
\hline $\mathrm{Cr}$ & 0.84 & 0.47 & 0.07 & 0.21 & 0.99 \\
\hline $\mathrm{Fe}$ & 0.88 & 0.39 & 0.11 & 0.25 & 0.99 \\
\hline K & 0.79 & 0.55 & 0.08 & 0.24 & 0.98 \\
\hline La & 0.89 & 0.06 & 0.16 & 0.34 & 0.94 \\
\hline $\mathrm{Mg}$ & 0.47 & 0.83 & 0.11 & 0.14 & 0.94 \\
\hline $\mathrm{Na}$ & 0.05 & 0.95 & 0.09 & 0.06 & 0.91 \\
\hline $\mathbf{P}$ & 0.65 & 0.51 & 0.19 & 0.19 & 0.75 \\
\hline Sc & 0.89 & 0.32 & 0.05 & 0.22 & 0.95 \\
\hline $\mathrm{Sr}$ & -0.87 & 0.07 & 0.14 & 0.26 & 0.86 \\
\hline Ti & 0.86 & 0.18 & 0.22 & 0.32 & 0.92 \\
\hline V & 0.87 & 0.35 & 0.09 & 0.3 & 0.98 \\
\hline $\mathbf{Y}$ & 0.88 & 0.18 & 0.15 & 0.37 & 0.96 \\
\hline $\mathrm{Zr}$ & 0.81 & 0.15 & 0.09 & 0.3 & 0.78 \\
\hline Eigenvalues & 26.17 & 4.36 & 2.61 & 1.14 & \\
\hline$\%$ of variation & 0.44 & 0.21 & 0.11 & 0.09 & \\
\hline
\end{tabular}

The highest correlation $(\geq|0.75|)$ are indicated in white with a black background and moderate $(0.5 \leq|\mathrm{r}|<0.75)$ correlation are indicated with gray background. Communality is indicated 
Table 4 Semivariogram models for fauna and synthetic factors spatial distributions

\begin{tabular}{lrlllc}
\hline Parameter & Range $(\mathrm{m})$ & Model & Nugget $(\mathrm{CO})$ & Sill $(\mathrm{C})$ & Spatial dependency: $C 0 /(C+C 0)$ \\
\hline Meiofaunal diversity $(\mathrm{H})$ & 6676 & Gaussian & 0.05 & 0.15 & 25.17 \\
Meiofaunal abundance & $3,038,827$ & Exponential & $1.00 \mathrm{E}+06$ & $1.98 \mathrm{E}+07$ & 4.81 \\
Foraminiferal diversity $(\mathrm{H})$ & 1083 & Spherical & 0.02 & 0.06 & 0.26 \\
Foraminiferal density & 3187 & Gaussian & 30.0 & 3.91 & 0.88 \\
Synthetic factor 1 & 7399 & Spherical & 0.20 & 0.97 & 17.16 \\
Synthetic factor 2 & 15,455 & Spherical & 0.10 & 2.07 & 4.61 \\
Synthetic factor 3 & 7891 & Spherical & 0.10 & 1.32 & 7.02 \\
Synthetic factor 4 & 4840 & Spherical & 0.50 & 0.59 & 45.71 \\
\hline
\end{tabular}

